\title{
THE
}

\section{Losing the Future: Household Wealth from Urban Housing Demolition and Children's Human Capital in China}

\author{
Feng Li
}

Jing Jian Xiao

University of Rhode Island, jjxiao@uri.edu

Follow this and additional works at: https://digitalcommons.uri.edu/hdf_facpubs

The University of Rhode Island Faculty have made this article openly available.

Please let us know how Open Access to this research benefits you.

This is a pre-publication author manuscript of the final, published article.

Terms of Use

This article is made available under the terms and conditions applicable towards Open Access

Policy Articles, as set forth in our Terms of Use.

\section{Citation/Publisher Attribution}

Li, F. \& Xiao, J. J. (2020). Losing the Future: Household Wealth from Urban Housing Demolition and Children's Human Capital in China. China Economic Review, 63, 101533. doi: 10.1016/ j.chieco.2020.101533

Available at: https://doi.org/10.1016/j.chieco.2020.101533

This Article is brought to you for free and open access by the Human Development and Family Science at DigitalCommons@URI. It has been accepted for inclusion in Human Development and Family Science Faculty Publications by an authorized administrator of DigitalCommons@URI. For more information, please contact digitalcommons-group@uri.edu. 
China Economic Review, forthcoming.

\title{
Losing the Future: Household Wealth from Urban Housing \\ Demolition and Children's Human Capital in China
}

\author{
Feng LI, Renmin University of China
}

Jing Jian Xiao, University of Rhode Island

August 2020 


\title{
Losing the Future: Household Wealth from Urban Housing
}

\section{Demolition and Children's Human Capital in China}

\begin{abstract}
Some literature observes the negative but not very significant effect of household wealth growth on children's educational outcomes. This surprising finding is not easily reconciled with the traditional explanation that relaxed economic constraints caused by wealth growth can promote human capital accumulation. This paper proposes an alternative explanation for the causal relationship between wealth growth and human capital, which could be negative: individuals tend to reduce human capital investment following the decline in their labor supply induced by wealth growth, given that investing in human capital is mainly for employment competitiveness. This explanation is supported by evidence from the case of urban housing demolition in China, in which affected households could obtain substantial wealth growth by considerable demolition compensation thanks to the real estate boom in China. Specifically, using two nationally representative datasets, we find that Chinese households that have experienced demolition relatively have more wealth, less labor supply, lower propensity to accumulate children's human capital, and consequently, have children with lower educational achievement. These results suggest that China's economy may be losing its momentum because of the decline in labor supply and human capital accumulation brought about by the ongoing large-scale urban housing demolition.
\end{abstract}

Keywords: urban housing demolition, household wealth, labor supply, human capital JEL Classifications: J2, R380, P360

\section{Introduction}

Does household wealth growth improve children's human capital, especially for instant and substantial wealth growth such as winning a lottery? If the lack of wealth constrains human 
capital investment, as Becker and Tomes (1986) propose, an increase in wealth should relax budget constraints and help accumulate human capital, such as in the abundant findings of Filmer and Schady (2011), Lovenheim (2011), and Dahl and Lochner (2012). However, Picchio et al. (2017) and Cesarini et al. (2017) have demonstrated that exogenous wealth growth from winning a lottery would reduce labor supply. Intuitively, in such situation, because of the decreased labor supply, human capital accumulation could be less necessary given that the main reason for human capital accumulation is to promote employment competitiveness. Therefore, these lottery winners are probably less motivated to invest in human capital. Following this line, the outcomes of human capital accumulation related to wealth growth could be logically negative.

Notably, some seminal studies (Bleakley and Ferrie, 2016; Cesarini et al., 2016) have not demonstrated the positive effect of winning a lottery on educational outcomes of children and grandchildren. By contrast, they have observed a negative but not very significant effect, but they do not provide a deeper exploration of these unusual results which Bleakley and Ferrie (2016) refer to as "shocking behavior". Nevertheless, Hällsten and Pfeffer (2017) interpret the surprising finding of Cesarini et al. (2016) as strong evidence that Swedish households do not have economic constraints on education because of tuition-free education in Sweden. Bleakley and Ferrie (2016) infer that the role of household financial resources is limited in the formation of human capital of the next generations, in the unique historical environment they investigated. However, except for these two explanations for the no observation of the significantly positive effect, could household wealth growth have a negative effect on children's human capital, particularly when educational participation is not constrained by economic resources?

In this study, we suggest that an alternative explanation for the association between household wealth growth and children's human capital, which could be negative, may be at work. When wealth increases significantly and labor supply thereby decreases, the importance of labor earnings and human capital accumulation should decrease. As a consequence, individuals tend to 
relax their efforts to invest in the human capital of their children, and this eventually reduces the children's educational achievement. Additionally, adults who have children have usually completed their education, leaving little scope to alter their own human capital.

The unique case of urban housing demolition (UHD) in China offers several advantages when examining this explanation. First, thanks to the real estate boom, Chinese UHD resulting from large-scale urban renewal and real estate development could result in considerable economic compensation for affected households in the form of lump sums of money and real estate (Cai et al., 2018; Li et al., 2019). These financial windfalls for Chinese UHD households provide an opportunity to observe the significant wealth effects in China, namely, the association between household wealth growth and children's human capital. Second, UHD is widespread in China. According to data from the 2013 Chinese Household Income Project, 13.30\% of Chinese urban households had already experienced UHD by 2013 . Third, economic constraints should not be a primary obstacle to children's education in China because the law that requires 9 years of compulsory education and the free compulsory education reform were implemented in 1986 and 2006, respectively (Xiao et al., 2017). In addition, the tuition fee in high schools and universities is relatively much lower than in the United States, and low-interest student loans are available. The Chinese condition of much lower economic constraints to educational participation allows us to more easily observe the potential negative effect of wealth. Otherwise, the positive effect on relaxing economic constraints could offset the negative effect such that the real effect of wealth growth may be blurred.

We provide a series of evidence for our explanation by exploiting this UHD case in China. We examine the nationally representative panel data from the Chinese Family Panel Studies across 25 provinces by using the difference-in-differences (DID) approach. UHD in China increases household wealth substantially. Specifically, UHD households on overage have more houses (0.22 in number and at least RMB 276,241 in value) and more cash and bank 
deposits (at least RMB 71,588 in value) after experiencing UHD, compared with non-UHD households. The estimated wealth growth for households that have experienced UHD is nearly equivalent to 15 years of individual income in China, based on the Chinese per capita disposable income in 2016 from the National Bureau of Statistics of China.

Consequently, UHD with considerable wealth growth reduces individual labor supply. The probability of being employed decreases by 3.77 percentage points caused by UHD overall, and the magnitude is much larger for women than men (8.79 percentage points for women vs. 1.48 percentage points for men). Furthermore, the finding of the positive effect of UHD on individual life satisfaction could rule out the possibility that the decline in labor supply is from the negative effects of UHD, such as the forced evictions documented in Ho (2013b). Eventually, it results in the reduction of children's human capital accumulation as predicted by our explanation. Affected by UHD, adults have lower propensity to accumulate their children's human capital, indicated by 1.88 hours less of weekly tutoring their children and a 13.01 percentage point lower probability to expect that their children obtain at least a bachelor's degree. We further find evidence of relatively lower educational achievement for UHD group by the cross-sectional data from the 2013 Chinese Household Income Project. Children who experienced UHD before sitting for the College Entrance Test $(\mathrm{CET})^{1}$ have CET scores nearly 20 points lower and a probability to enter elite universities in China that is ten percentage points lower compared with children who never experienced UHD. Similarly, children who experienced UHD before sitting for the High School Entrance Test (HET) are approximately 13 percentage points less likely to enter key high schools. However, we do not observe the same patterns for the comparisons between children who experienced UHD after CET or HET and those who never

\footnotetext{
${ }^{1}$ That is, households where children are from experienced UHD before children's CET.
} 
experienced UHD, suggesting UHD-related confounding factors, such as family size, are not dominant in our results.

Our study contributes to the literature on wealth growth and human capital accumulation. As Hällsten and Pfeffer (2017) stress, exogenous wealth growth in a short time may lack the same social conditions of wealth accumulated and passed down over generations, such as related social norms. Therefore, the literature most relevant to our study is on exogenous wealth shocks, for example, cash transfer or other types of windfalls, and not accumulated family wealth. Researchers have concluded that increased wealth by cash transfer could have a positive influence on children's human capital accumulation (Schultz, 2004; Case et al., 2005; De Janvry et al., 2006; Filmer and Schady, 2011; among many others). Moreover, wealth growth from liquid houses can promote investment in children's human capital (Lovenheim, 2011). Increased income from the changes in the Earned Income Tax Credit in the United States has a positive effect on children's educational achievement (Dahl and Lochner, 2012). Among them, Filmer and Schady (2011) further observe that a larger cash transfer could not have a larger positive impact on school enrollment of children than a modest cash transfer. Lovenheim (2011) asserts that the effect of wealth growth is mostly localized to lower-resource families. These two pieces of supplementary evidence might suggest the positive effect of wealth growth on human capital could be limited if economic constraints for educational participation have been almost relaxed. Our study is closest to Bleakley and Ferrie (2016) and Cesarini et al. (2016), that is, in contrast with the aforementioned literature, they demonstrated a negative but not very significant effect. Nevertheless, no studies have clearly documented the negative effect of wealth growth on human capital, resulting in the scope for the explanation proposed and examined by our study.

Another main finding of our study - that the wealth from UHD reduces individual labor supply—also supports recent research on the causal relationship between wealth and labor 
supply. van Huizen (2014), Picchio et al. (2017), and Cesarini et al. (2017) have provided solid evidence by using large samples from affluent countries (i.e., Sweden and the Netherlands) that windfalls negatively affect labor supply. However, for reasons such as the lack of available data, researchers have focused less on the wealth effects in China, where household wealth has been increasing significantly (Xie and Jin, 2015) and the labor shortage is becoming a prominent problem (Cui et al., 2018). Our finding in China, a country of diligent individuals whose government does not provide an adequate social safety net, lends further support to this relationship between wealth and labor supply. In addition, we find the magnitude of labor supply decrease induced by wealth growth is much larger for women than men. This result suggests a social norm in China may play a critical role, that is, men leave home to work while women remain at home and perform the work of household chores, such as explored by Chen and Ge (2018).

Our study extends the understanding of real estate development in China from a new perspective. With the real estate industry becoming China's economic pillar, the real estate boom and the subsequent risks of bursting bubbles have drawn much research attention. Although Glaeser et al. (2017) are optimistic about the housing bubble in China, detrimental consequences of rapid increases in housing prices have occurred. Li and Wu (2014) find that high housing prices in general discourage entrepreneurial activities for urban adults in China. Chen et al. (2018) show that housing unaffordability crowds out elites in Chinese superstar cities. Wrenn et al. (2019) ascribe part of the decline in rates of initial marriage in China to the increase in housing prices. Our study contributes to this strand of research by exploiting the case of UHD behind the real estate development in China. We conclude that UHD is at the cost of the decline in labor supply and human capital accumulation, a phenomenon that would probably lead to China's economy losing its momentum. 
The rest of our paper is divided into the following sections. Section 2 provides policy background of UHD and education system in China. Section 3 describes the data and variables used in our study. Section 4 details the empirical strategy we employ. Section 5 presents the empirical findings. Section 6 concludes our paper.

\section{Policy background}

\subsection{Urban housing demolition in China}

Due to the limitation of land resources, the rapid urbanization of cities in China since the reform and opening-up policy in the late 1970s has occurred at the cost of massive demolition of existing old urban buildings. Following the emergence of the real estate market in the 1990s and the real estate boom since the 2000 s, the skyrocketing housing prices have further reinforced the large-scale UHD conducted in China to free up land for real estate development, a phenomenon driven by local governments and property developers in the name of urban renewal. Specifically, $13.30 \%$ of Chinese urban households had experienced UHD by 2013, based on data from the 2013 Chinese Household Income Project. The overall number of households affected by UHD has increased continuously: $2.14 \%$ and $2.19 \%$ of Chinese urban households experienced UHD in 2013 and 2015, respectively, according to data from the Chinese Family Panel Studies. Moreover, UHD remains the priority of the Chinese government's economic policy because the top economic development plan, the 13th Five Year Plan (2016-2020), stresses that China will continue to improve urbanization by developing new towns and optimizing urban space.

UHD, urban renewal, and real estate development have largely contributed to the rapid growth of the economy in China and to the improvement in urban landscape and housing conditions of urban residents. However, the side effects of this process are also prominent and deeply affect Chinese society and economic development, namely, housing prices are a financial burden for residents, houses represent a substantial amount of household wealth, and thus 
individuals and households have changed their behavior substantially ( $\mathrm{Li}$ and $\mathrm{Wu}, 2014$; Fu et al., 2016; Chen et al., 2018; Fang and Tian, 2018; Wrenn et al., 2019; Zou and Deng, 2019). Notably, the economic studies of UHD in China have been insufficient except for some examples in the anthropology, urban and regional literature (Ho, 2013a,b; Zhang, 2018; Day and Cervero, 2010) that have reported on surveys of the side effects of forced evictions, bargaining during demolition, and residential relocation caused by UHD.

The household wealth gains from UHD remain unclear. Ho (2013a) and Wong (2015) have mentioned that UHD may lead to substantial wealth gains for affected households, but this argument has not been examined by representative data. Li and Song (2009) use a survey of 1200 households conducted in Shanghai in 2006 and find that the housing conditions of displaced households thanks to UHD are somewhat better. However, they do not calculate the details of wealth growth induced by UHD including house and money of households. Therefore, more careful investigations of the wealth effects of UHD are necessary.

\subsection{Chinese education system}

The Chinese education system basically comprises four levels: elementary school, middle school, high school, and university. Students sit for two important national tests: the HET and CET. The HET and CET scores determine whether children enter high schools or universities for further higher-level education as well as key high schools or elite universities for higher-quality education. Chinese children aged 6 or 7 usually start their education in elementary schools. The law that implemented 9 years of compulsory education and the free compulsory education reform were introduced in 1986 and 2006, respectively (Xiao et al., 2017). Thus, 6 years of elementary school and 3 years of middle school are a basic requirement for Chinese children, and not constrained by parents' income. Moreover, in China, attending a public high school or university costs approximately $\$ 200$ or $\$ 700$ per year, much lower than in the United States. If children's parents cannot afford the tuition, they can apply for low-interest student loans. Hence, economic 
constraints may not be an apparent obstacle for Chinese children to acquire education and accumulate human capital. Instead, other factors could play a more notable role, such as the willingness and determination of parents and children to achieve educational success.

The Chinese education system is the main path for Chinese children to accumulate human capital. According to data from the 2013 Chinese Household Income Project, $0.005 \%$ of Chinese citizens have a foreign bachelor's degree, although studying abroad is becoming an increasingly popular choice as a means for wealthy parents and students to avoid the fierce education competition in China. However, most Chinese parents and children are still heavily incentivized to do well in Chinese education system if they attach importance to the investment in human capital of children. Notably, most ordinary Chinese households do not have the capacity to afford the high cost of studying abroad. To be well educated and accumulate more human capital, these Chinese parents and children can merely try their best to earn the highest scores as possible on the HET and CET. In this manner, ordinary Chinese could earn the very limited slots in key high schools and elite universities. Moreover, a prevailing notion in China is that studying at the elite universities is a promising means to promote employment competitiveness in the future labor market (Li et al., 2012; Jia and Li, 2016). Therefore, the performances on the HET and CET are reasonable indicators of human capital accumulation of children.

Usually, elite universities in China refer to those financially supported by Project 211 and Project 985, initiated by the Chinese government to increase the research standards of high-level universities in China. There are 116 universities (nearly $6 \%$ of all universities) supported by Project 211, among which the best 39 universities are further supported by Project 985 . All these 116 universities are regarded as the elite universities in our study. 


\section{Data and descriptive statistics}

In this section, we roughly display the association between household wealth from UHD and children's human capital accumulation in China by presenting descriptive statistics. In Figure 1, we present the density plot of children's CET scores of two subgroups from the full sample: one subgroup for children who experienced UHD before their CET (UHD children) and the other subgroup for children who never experienced UHD (non-UHD children). The vertical axis represents CET scores, and the horizontal axis stands for probability density. We clearly observe in Figure 1 that the CET score probability density curve of UHD children (solid curve) is on the left of that of non-UHD children (dash curve). This observation obviously indicates the relatively lower CET scores for UHD children compared with non-UHD children. This finding is consistent with the hypothesis of the negative effect of household wealth from UHD on children's human capital accumulation. Notably, the finding is not a rigorous proof by itself. More detailed information and regressions are necessary.

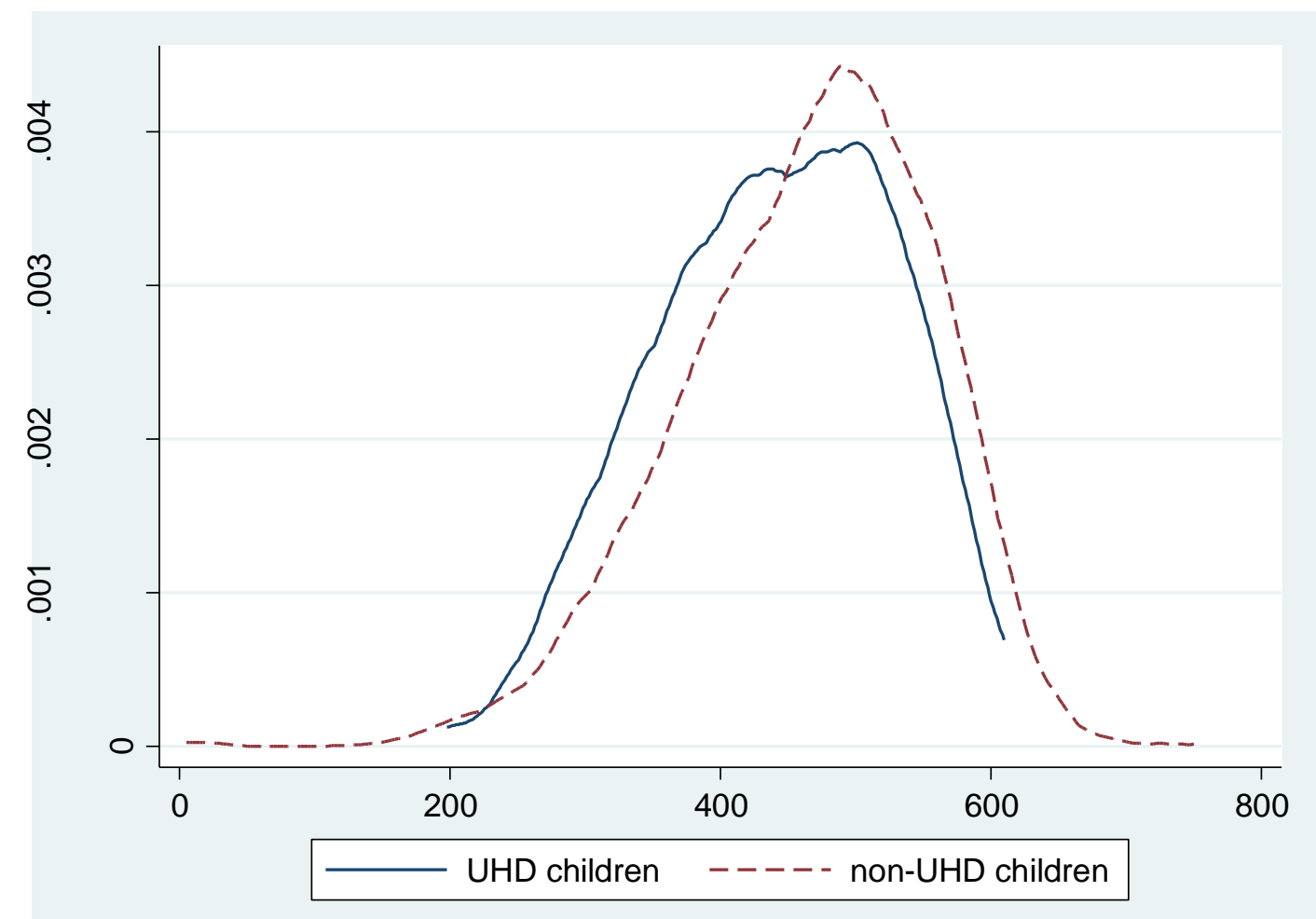


Figure 1. Density plot of children's CET scores

Notes: The vertical axis represents CET scores and the horizontal axis stands for probability density. The dash probability density curve depicts the distribution of CET scores for the non-UHD children, and the solid curve depicts for the UHD children who experienced UHD before sitting for the CET. The relative positions of these two curves indicate the lower CET scores for UHD children. This finding is in line with the hypothesis of the negative effect of household wealth from UHD on children's human capital accumulation. The information on children's CET scores is from the 2013 CHIP data.

To set the stage for latter regressions, we first provide more detailed information on the descriptive statistics of main variables from the Chinese Family Panel Studies (CFPS) data in Section 3.1. and the 2013 Chinese Household Income Project (CHIP) data in Section 3.2. We mainly compare the outcomes of these variables between UHD and non-UHD subgroups to demonstrate the basic similarities and differences between these two subgroups and provide some preliminary results of the influences of UHD.

\subsection{Data from the Chinese Family Panel Studies}

We use the CFPS data to compare the outcomes of households and individual adults before and after UHD, including household wealth condition, individual labor supply, life satisfaction and propensity to accumulate children's human capital. The CFPS data is a nationally representative, annual longitudinal survey that has been conducted by the Institute of Social Science Survey of Peking University every 2 years since 2010. Due to the availability of information on UHD, we employ the CFPS data of only urban households and urban adults from 25 provinces and the waves of 2012, 2014, and 2016.

The key variable of our study is the information on UHD. Only in the waves of 2014 and 2016 is information provided on UHD by asking whether households experienced UHD in the past 12 months $^{2}$. Because the surveys were conducted in 2014 and 2016, we consider that the

UHD information corresponds to UHD carried out in 2013 and 2015. The wave of 2012 is used to

\footnotetext{
${ }^{2}$ Besides the waves of 2014 and 2016, in the wave of 2010 there is a question to ask whether households had ever experienced UHD before, so that we can identify those who had experienced UHD before 2010. Among households without UHD in 2013 and 2015, 600 households had experienced UHD before 2010. Nevertheless, our results still remain robust if we drop these observations.
} 
represent the condition before UHD. Panel A of Table 1 shows that 117 households (1.72\%) and 284 individual adults (1.75\%) experienced UHD in 2013, and 148 households (2.14\%) and 351 individual adults $(2.19 \%)$ experienced UHD in $2015^{3}$.

In the subsequent panels of Table 1, each panel pertains to one dimension of our study including the related variables. Column (1) comprises means and standard errors (in parentheses) of variables for the full sample, and columns (2) and (3) report the corresponding values for the samples of UHD households (individuals) and non-UHD households (individuals). We use a simple bivariate regression on a dummy variable for UHD households (individuals) to test the differences between UHD and non-UHD households (individuals). The results are presented in column (4), which comprises regression coefficients (i.e., mean differences between UHD and non-UHD groups) and standard errors in parentheses. We also mark the significance levels of these differences with stars.

Panel B and Panel C display outcomes of households and individuals separately before UHD, which are not supposed to be affected by whether these households and individuals experienced UHD in the following years. In column (4), we find no significant differences in number of children; household income; and an individual's age, gender, and education years. However, column (4) does show that houses of UHD households before UHD are significantly much older (3.67 years older) than those of non-UHD households, indicating that one of the aims of UHD in China is urban renewal that mainly targets demolition and reconstruction of relatively older buildings (Zhang and Fang, 2004). Although UHD may not be completely random and is

\footnotetext{
${ }^{3}$ Considering that the observations of UHD households and individuals are much fewer than those without UHD, we also conduct all the regressions again in which we match every UHD household and individual to those without UHD but having the same family size and children number, and at the same age level and education level, and in the same province. In this way, we compare 265 UHD households (635 UHD individuals) in the waves of 2014 and 2016 with 2766 non-UHD households (8304 non-UHD individuals). Therefore, the share of UHD households in total households increases from $1.97 \%$ (before matching) to 9.58\% (after matching), and the share of UHD individuals in total individuals increases from $2.01 \%$ (before matching) to $7.63 \%$ (after matching). Our conclusions hold whether we do matching or not.
} 
inevitably affected by household characteristics including house age and family size, we can include household or individual fixed effects in our regression equations to address this concern by using panel data and the DID approach.

\section{Table 1}

Descriptive statistics of the CFPS data

\begin{tabular}{|c|c|c|c|c|}
\hline & $\begin{array}{l}\text { Full sample } \\
\text { (1) }\end{array}$ & $\begin{array}{l}\text { UHD } \\
\text { (2) }\end{array}$ & $\begin{array}{l}\text { Non-UHD } \\
\text { (3) }\end{array}$ & $\begin{array}{l}\text { Mean } \\
\text { differences } \\
\text { (4) }\end{array}$ \\
\hline \multicolumn{5}{|l|}{ Panel A: sample size } \\
\hline \multicolumn{5}{|l|}{ Wave of 2012} \\
\hline Households & 6050 & & & \\
\hline Adults & 15215 & & & \\
\hline \multicolumn{5}{|c|}{ Wave of 2014 (UHD information from 2013) } \\
\hline Households & 6789 & 117 & 6672 & \\
\hline Adults & 16230 & 284 & 15946 & \\
\hline \multicolumn{5}{|c|}{ Wave of 2016 (UHD information from 2015) } \\
\hline Households & 6901 & 148 & 6753 & \\
\hline Adults & 16009 & 351 & 15658 & \\
\hline \multicolumn{5}{|c|}{$\begin{array}{l}\text { Panel B: predetermined outcomes at household } \\
\text { level }\end{array}$} \\
\hline Family size & $\begin{array}{l}3.5104 \\
(1.6038)\end{array}$ & $\begin{array}{l}3.6766 \\
(1.7925)\end{array}$ & $\begin{array}{l}3.5017 \\
(1.5931)\end{array}$ & $\begin{array}{l}0.1748^{*} \\
(0.0945)\end{array}$ \\
\hline Children number & $\begin{array}{l}0.5227 \\
(0.7424)\end{array}$ & $\begin{array}{l}0.5182 \\
(0.7495)\end{array}$ & $\begin{array}{l}0.5229 \\
(0.7421)\end{array}$ & $\begin{array}{l}-0.0047 \\
(0.0438)\end{array}$ \\
\hline Income & $\begin{array}{l}54528.99 \\
(86053.83)\end{array}$ & $\begin{array}{l}50813.07 \\
(49998.36)\end{array}$ & $\begin{array}{l}54730.5 \\
(87584.36)\end{array}$ & $\begin{array}{l}-3917.429 \\
(5243.195)\end{array}$ \\
\hline House age & $\begin{array}{l}13.1834 \\
(10.4783)\end{array}$ & $\begin{array}{l}16.6763 \\
(11.7736)\end{array}$ & $\begin{array}{l}13.0105 \\
(10.3811)\end{array}$ & $\begin{array}{l}3.6658 * * * \\
(0.7441)\end{array}$ \\
\hline \multicolumn{5}{|c|}{$\begin{array}{l}\text { Panel C: predetermined outcomes at individual } \\
\text { level }\end{array}$} \\
\hline Age & $\begin{array}{l}45.1474 \\
(16.8801)\end{array}$ & $\begin{array}{l}45.7330 \\
(16.6955)\end{array}$ & $\begin{array}{l}45.1205 \\
(16.8886)\end{array}$ & $\begin{array}{l}0.6125 \\
(0.6630)\end{array}$ \\
\hline Gender $(1=$ male, $0=$ female $)$ & $\begin{array}{l}0.4822 \\
(0.4997)\end{array}$ & $\begin{array}{l}0.4779 \\
(0.4999)\end{array}$ & $\begin{array}{l}0.4824 \\
(0.4997)\end{array}$ & $\begin{array}{c}-0.0045 \\
(0.0196)\end{array}$ \\
\hline Education years & $\begin{array}{l}8.1419 \\
(4.8603)\end{array}$ & $\begin{array}{l}8.0164 \\
(4.5394)\end{array}$ & $\begin{array}{l}8.1476 \\
(4.8745)\end{array}$ & $\begin{array}{r}-0.1312 \\
(0.1917)\end{array}$ \\
\hline \multicolumn{5}{|c|}{$\begin{array}{l}\text { Panel D: household wealth condition } \\
\text { House number }\end{array}$} \\
\hline Before UHD & $\begin{array}{l}1.1932 \\
(0.4733)\end{array}$ & $\begin{array}{l}1.2440 \\
(0.4930)\end{array}$ & $\begin{array}{l}1.1908 \\
(0.4723)\end{array}$ & $\begin{array}{l}0.0532 \\
(0.0335)\end{array}$ \\
\hline After UHD & $\begin{array}{l}1.2606 \\
(0.5545)\end{array}$ & $\begin{array}{l}1.4922 \\
(0.8173)\end{array}$ & $\begin{array}{l}1.2509 \\
(0.5387)\end{array}$ & $\begin{array}{l}0.2414 * * * \\
(0.0406)\end{array}$ \\
\hline \multicolumn{5}{|l|}{ House value, in RMB 10,000} \\
\hline Before UHD & $\begin{array}{l}48.7092 \\
(82.3207)\end{array}$ & $\begin{array}{l}49.9338 \\
(69.2859)\end{array}$ & $\begin{array}{l}48.6513 \\
(82.8920)\end{array}$ & $\begin{array}{l}1.2824 \\
(5.8418)\end{array}$ \\
\hline After UHD & $\begin{array}{l}94.2893 \\
(490.7659)\end{array}$ & $\begin{array}{l}303.8779 \\
(2176.093)\end{array}$ & $\begin{array}{l}85.5355 \\
(228.4923)\end{array}$ & $\begin{array}{l}218.3423 * * * \\
(36.0158)\end{array}$ \\
\hline \multicolumn{5}{|c|}{ Cash and bank deposits, in RMB 10,000} \\
\hline Before UHD & $\begin{array}{l}4.2141 \\
(12.8740)\end{array}$ & $\begin{array}{l}3.3649 \\
(7.8933)\end{array}$ & $\begin{array}{l}4.2579 \\
(13.0785)\end{array}$ & $\begin{array}{l}-0.8929 \\
(0.7975)\end{array}$ \\
\hline After UHD & 6.6598 & 10.9055 & 6.4174 & $4.4881 * * *$ \\
\hline
\end{tabular}




$(19.1515) \quad(34.6408) \quad(17.8414)$

Panel E: individual labor supply (1=employed, $0=$ unemployed)

Before UHD

$\begin{array}{llll}0.5883 & 0.5914 & 0.5882 & 0.0033 \\ (0.4922) & (0.4919) & (0.4922) & (0.0193) \\ 0.6450 & 0.5540 & 0.6496 & -0.0956^{* * *} \\ (0.4785) & (0.4974) & (0.4771) & (0.0176)\end{array}$

Panel F: life satisfaction, from 1 (strongly unsatisfied) to 5 (strongly satisfied) Before UHD

After UHD

$\begin{array}{llll}3.3500 & 3.4550 & 3.3449 & 0.1100^{* * *} \\ (1.0404) & (1.0283) & (1.0408) & (0.0413) \\ 3.6216 & 3.7533 & 3.6152 & 0.1381^{* * *} \\ (1.0591) & (1.0240) & (1.0603) & (0.0396)\end{array}$

Panel G: propensity to accumulate children's human capital

Hours to tutor children for homework weekly Before UHD

$\begin{array}{llll}6.4671 & 6.7857 & 6.4571 & 0.3287 \\ (5.4940) & (6.3334) & (5.4680) & (0.8612) \\ 7.2460 & 6.9182 & 7.2601 & -0.3420 \\ (5.6261) & (5.0468) & (5.6512) & (0.7751)\end{array}$

Expect that children achieve at least a bachelor's degree $(1=$ yes, $0=$ no $)$

Before UHD

$\begin{array}{llll}0.8976 & 0.9123 & 0.8970 & 0.0153\end{array}$

After UHD

\section{$(0.3033)$}

(0.2854)

$0.8414 \quad 0.7857$

$(0.3041)$

$(0.0410)$

(0.3653)

$(0.4122)$

$(0.3635)$

0.0577

Notes. Descriptive statistics for the main variables employed are from the CFPS data. The sample comprises all urban households and urban individuals in the waves of 2012, 2014, and 2016 across 25 provinces in China. Panel A reports the sample size of each subgroup. The subsequent panels display means and standard deviations (in parentheses) of variables of different subgroups in columns (1), (2), and (3). Column (4) presents the results of a bivariate regression on a dummy for UHD groups including coefficients (i.e., mean differences between UHD and non-UHD groups) and standard errors in parentheses. $* * *, * *$, and $*$ mean that differences are significant at $1 \%, 5 \%$, and $10 \%$.

The remainder of Table 1 shows the results of comparisons at two folds, namely, differences between UHD and non-UHD groups, and changes from the pre-UHD to post-UHD era. These comparisons illustrate that the differences between UHD and non-UHD groups are driven by UHD per se rather than only the other confounding factors related to UHD. Panel D reports the wealth condition of UHD and non-UHD households and corresponding changes after UHD. We observe that before UHD, there are no significant differences in household wealth condition between UHD and non-UHD households in terms of house number, house value, and cash and bank deposits. However, after UHD, UHD households compared with non-UHD households have significantly more houses ( 0.24 in number and RMB 2,183,423 in value) and more cash and bank deposits (RMB 44,881 in value). This finding suggests UHD could result in 
substantial wealth growth for affected households, but the results are rough and do not include more control variables.

The outcomes regarding individual labor supply and life satisfaction are displayed in Panels E and F. We use a dummy variable for employed individuals, 1 for being employed and 0 for being unemployed, to measure labor supply in the extensive margin. Life satisfaction is reported by respondents on a scale, from 1 (strongly unsatisfied) to 5 (strongly satisfied). Labor supply does not differ between UHD and non-UHD individuals before UHD, and labor supply of UHD individuals displays a significant decrease relative to non-UHD individuals after UHD. This significant change implies the negative effect of UHD on individual labor supply. Although life satisfaction of UHD individuals is significantly higher than that of non-UHD individuals, before or after UHD, this gap increases further after UHD, suggesting the positive effect of UHD on individual life satisfaction.

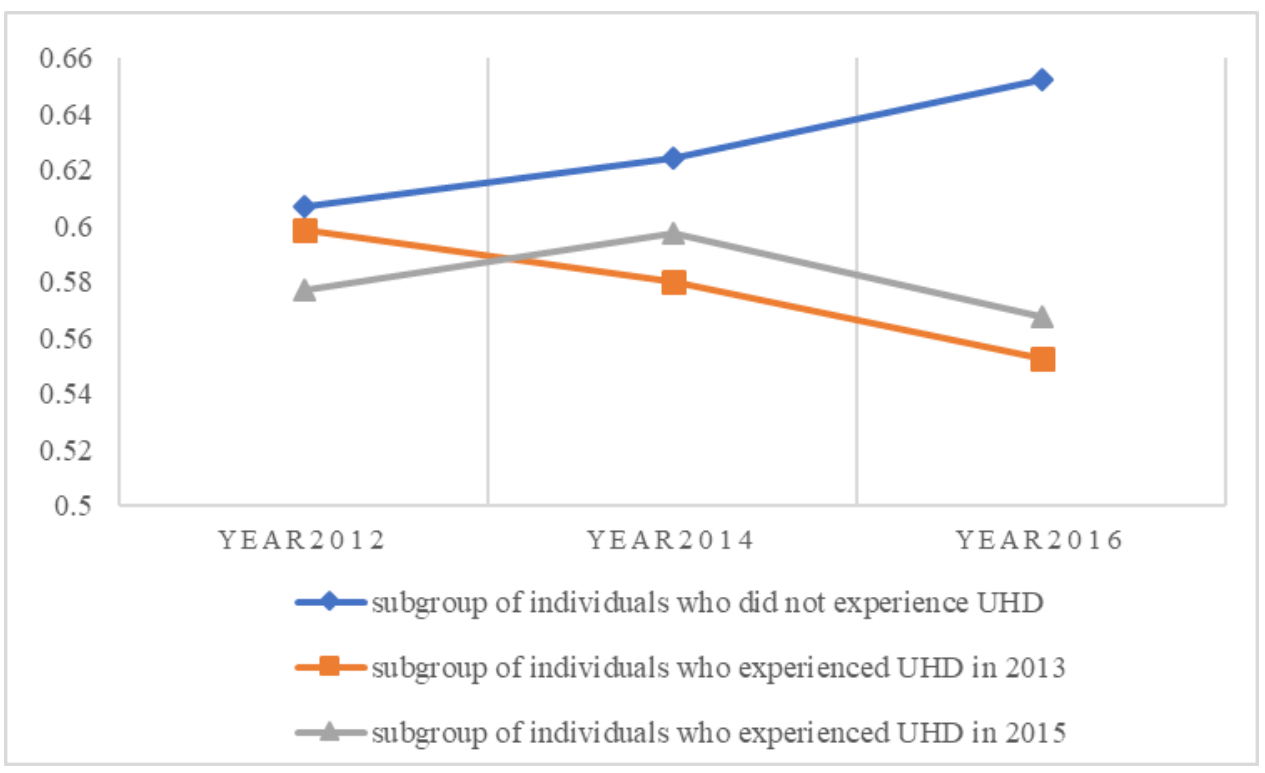

Figure 2. Time profiles of employment rates in relation to the timing of UHD

Notes: The full sample of individual adults is divided into three subgroups, non-UHD, UHD in 2013, and UHD in 2015. The horizontal axis stands for years and the vertical axis depicts employment rates by the formula (number of being employed divided by subsample size). The employment rates of UHD subgroups start to decrease, whereas that of non-UHD subgroup continues to increase, implying the negative effect of UHD on individual labor supply. The information on individual status of employment is from the CFPS data. 
Our explanation of the negative effect of household wealth from UHD on children's human capital accumulation connects the decline in individual adults' labor supply induced by UHD to human capital accumulation. Therefore, more detailed evidence is desirable on whether labor supply or working status, that is, being employed or unemployed, actually varies with the timing of UHD and whether the pattern differs between UHD and non-UHD individuals. With the available information, we trace out time-series profiles of employment rates of different subgroups with respect to UHD (Figure 2). The full sample of individual adults is divided into three subgroups: non-UHD, UHD in 2013, and UHD in 2015. Figure 2 plots time profiles of employment rates of these three subgroups, separately, where the horizontal axis stands for years and the vertical axis depicts employment rates by the formula (number of being employed divided by subsample size). The employment rate for non-UHD individuals continues to increase, but it starts to decrease for UHD subgroups only in the post-UHD era, suggesting that some of the UHD individuals give up their jobs after experiencing UHD. This finding thus implies the negative effect of UHD on labor supply.

Panel G summarizes the differences between the UHD and non-UHD groups and changes over time of adults' propensity to accumulate children's human capital. Due to the limitation of the CFPS data, we can only observe the changes in propensity to invest in children's human capital. Direct outcomes of children's human capital accumulation, such as educational achievement of children measured by CET and HET scores, are not available in this dataset. Hence, we use two variables to indicate propensity to accumulate children's human capital: hours to tutor children's homework weekly and a dummy variable for the expectation that their children achieve at least a bachelor's degree. Although the differences between UHD and non-UHD concerning these two variables are not significant, we observe the changes from the pre-UHD to post -UHD era. UHD adults have slightly more hours to tutor children and a higher probability to expect that their children achieve at least a bachelor's degree before UHD. However, after UHD, 
the values of these two variables are lower for UHD adults than non-UHD adults. These changes imply the relative decline in the propensity to accumulate their children's human capital for UHD adults after experiencing UHD.

\subsection{Data on children's educational achievement}

Hoekstra et al. (2018) estimate the cognitive returns to high school quality by using the CET scores of children in China. Following this way, we exploit the performance of children on the CET and HET to estimate the effect of UHD on children's educational achievement. Given the vital significance of HET and CET for Chinese children (Lu et al., 2018; Hoekstra et al., 2018), children's educational achievement measured by their performance on the CET and HET is an ideal indicator of their human capital accumulation. Data from the 2013 CHIP, a national cross-sectional survey of Chinese households, provides information on UHD, CET, and HET. Our sample comprises all urban children, that is, sons or daughters of household heads in the urban sample. This supplement is key to the analysis of the changes in adults' propensity to accumulate their children's human capital after experiencing UHD. Specifically, the UHD information is about whether and which year households that children belong to experienced UHD. CET information mainly records which year children sat for the CET, their CET scores, and whether they entered elite universities. HET information documents only whether children entered key high schools. HET scores are not available in this dataset. We define children who experienced UHD before they sat for the CET or HET as UHD children because only in this manner could UHD possibly affect their CET or HET performance. Non-UHD children are those who did not experience UHD before the survey was conducted. Due to the lack of information on which year the children sat for the HET, we calculate it by their birth years based on the assumption that usually children sit for the HET at age 16 years, considering that Chinese children generally begin elementary schools at age 7 years and spend 6 years in elementary school and 3 years in middle school. 
Table 2

Descriptive statistics of children's CET and HET performance from the CHIP data

\begin{tabular}{lcccc}
\hline & Full sample & UHD & Non-UHD & Mean differences \\
& $(1)$ & $(2)$ & $4)$ & $-23.0278 * *$ \\
& 461.5977 & 441.0189 & $(964.0466$ & $(9.3076)$ \\
CET scores & $(92.8481)$ & $(86.7713)$ & 0.1759 & $-0.1099 * * *$ \\
Enter elite universities & 0.1655 & 0.0659 & $(0.3809)$ & $(0.0407)$ \\
$(1=$ Yes, 0=No) & $(0.3718)$ & $(0.2495)$ & 0.4847 & $-0.1463 * * *$ \\
Enter key high schools & 0.4645 & 0.3384 & $(0.4999)$ & $(0.0369)$ \\
$(1=$ Yes, 0=No) & $(0.4988)$ & $(0.4744)$ &
\end{tabular}

Notes. Descriptive statistics of children's CET and HET performance are from the 2013 CHIP data. Means and standard deviations (in parentheses) of variables of different subgroups are displayed in columns (1), (2), and (3). Column (4) presents the results of a bivariate regression on a dummy for UHD groups including coefficients (i.e., mean differences between UHD and non-UHD groups) and standard errors in parentheses. $* * *, * *$, and * mean that differences are significant at $1 \%, 5 \%$, and $10 \%$.

Table 2 reports the educational outcomes of UHD children and non-UHD children. Column (1) displays means and standard deviations (in parentheses) of performance on the CET and HET for the full sample. Columns (2) and (3) present the corresponding values for UHD and non-UHD children, respectively. Column (4) reports the results of bivariate regression on a dummy variable for UHD children including coefficients (i.e., mean differences between UHD children and non-UHD children) and standard errors in parentheses. Obviously, significant gaps are observed in CET and HET performance between UHD children and non-UHD children consistent with the illustration of Figure 1. On average, for non-UHD children, CET scores are 464.05 points, the probability of entering elite universities is $17.59 \%$, and the probability of entering key high schools is $48.47 \%$. Compared with non-UHD children, UHD children score 23.03 points less on the CET, and are much less likely to enter elite universities (i.e., 10.99 percentage points less) and key high schools (i.e., 14.63 percentage points less). These descriptive statistics could provide approximate insights into the profound consequences of UHD for children's educational achievement, implying the relative reduction of human capital accumulation for those children affected by UHD. 


\section{Estimation strategy}

UHD may not be completely randomized and is related to family size and house age (Panel B of Table 1), because of the aim of Chinese UHD. Therefore, the main empirical challenge of our study is to identify the pure effects of UHD by distinguishing the effects of UHD from other confounding factors such as individual and household characteristics.

For the panel data from the CFPS, we use the DID approach to capture the differences between UHD group and non-UHD group (first difference) and the changes within groups from the pre-UHD to post-UHD era (second difference). Thereby, we can control for time-constant confounding factors at the individual or household level such as house age by including individual or household fixed effects in regressions. This DID approach also enables us to include province-year fixed effects, which can effectively control for all time-varying differences across provinces such as economic policies associated with both UHD and economic growth.

We implement the DID approach at the household level in regression equation (1):

$y_{h t}=\alpha+\beta U H D_{h} \times$ post $_{t}+\gamma X_{h t}+\delta X_{h} \times y e a r_{2014}+\theta X_{h} \times y e a r_{2016}+\mu_{h}+\mu_{p t}+\varepsilon_{h t}$,

where $y_{h t}$ is three measures of the wealth condition of household $h$ in year $t$ including number of houses, value of these houses, and amount of cash and bank deposits. Our key regressor is the DID term, which is an interaction of two dummy variables: one dummy for UHD households, namely, households that have experienced UHD, and one dummy for the post-UHD era. The coefficient of interest is the estimate on this DID term, $\beta$, which measures the extra wealth changes of UHD households in the post-UHD era relative to non-UHD households. $\beta$ is supposed to be significantly positive if Chinese UHD households obtain significant wealth growth thanks to UHD compensation. The vectors $\mu_{h}$ and $\mu_{p t}$ are full sets of household and province-year fixed effects to control for household-specific time-invariant factors and province-specific time-varying factors. $X_{h t}$ is the control variables, both time-varying and household-specific, containing family 
size, number of children in the household, household head age, and its squared term. To address the potential dynamic effects of time-invariant variables at the household level, we also incorporate the interactions of the variable $X_{h}$ and year dummy variables in the regression equations. In this part, $X_{h}$ is only education years of household head, which may have differential effects on household wealth condition in different years with various economic climates. $\varepsilon_{h t}$ is the error term. Standard errors of estimated coefficients are clustered over the household level.

We estimate a similar regression equation at the individual adult level concerning the individual labor supply in the extensive margin and individual life satisfaction by employing the DID approach as follows:

$$
y_{i h t}=\alpha+\beta U H D_{h} \times \text { post }_{t}+\gamma X_{i h t}+\delta X_{i h} \times \text { year }_{2014}+\theta X_{i h} \times \text { year }_{2016}+\mu_{i}+\mu_{p t}+\varepsilon_{i h t},
$$

where $y_{i h t}$ is two outcomes of individual $i$ from household $h$ in year $t$. Dependent variables at the individual level contain a dummy variable for being employed and a variable on a 5-point scale for life satisfaction, 1 (strongly unsatisfied) to 5 (strongly satisfied). These two variables are used to examine the effects of UHD on individuals' labor supply and life satisfaction. The key regressor, the DID term, is the same as that in equation (1). Individual fixed effects $\mu_{i}$ and province-year fixed effects $\mu_{p t}$ are also included in regression equations to control for confounding factors. Time-varying control variable $X_{i h t}$ includes family size and number of children in the household $h$ where individual $i$ is from, age, and its squared term of individual $i$ in year $t$. Timeinvariant variable $X_{i h}$, which may have dynamic effects, is an individual's education years and gender. $\varepsilon_{i h t}$ is the error term. Standard errors of estimated coefficients are clustered over the household level.

Our regression equation for adults' propensity to accumulate their children's human capital is slightly different from equation (2) as follows:

$$
y_{i c h t}=\alpha+\beta U H D_{h} \times \text { post }_{t}+\gamma X_{i c h t}+\delta X_{i c h} \times \text { year }_{2014}+\theta X_{i c h} \times \text { year }_{2016}+\mu_{c}+\mu_{p t}+\varepsilon_{i c h t},
$$


where $y_{i c h t}$ is the propensity of individual $i$ and household $h$ to accumulate human capital of child $c$, which is indicated by hours spent weekly tutoring child $c$ for homework completion and a dummy variable for the expectation that child $c$ would obtain at least a bachelor's degree. In this part of the survey, individual $i$ refers to the adult member of household $h$ who answers these children-related questions. Children fixed effects $\mu_{c}$ are included in addition to province-year fixed effects $\mu_{p t}$ to control for confounding factors. Time-varying control variable $X_{i c h t}$ includes family size and number of children in household $h$ where child $c$ and individual $i$ are from, age, and its squared term of individual $i$ and child $c$ in year $t$. Time-invariant variable $X_{i c h}$, which interacts with year dummy variables, includes gender ( 1 for male, 0 for female) and education years of individual $i$, and gender ( 1 for boys, 0 for girls) of child $c$. $\varepsilon_{i c h t}$ is the error term. Standard errors of estimated coefficients are clustered at the household level.

We further exploit the outcomes of children's human capital accumulation measured by their educational achievement, namely, the performance of children on the CET and HET. These are two most important exams for Chinese as studying at elite universities would help them obtain a much higher wage (Li et al., 2012; Jia and Li, 2016). Cross-sectional data from the 2013 CHIP provides information on households' UHD, and children's performance on the CET and HET. Although CET is a nationwide standardized examination, the competition in the CET is among the children from the same province because each province has an independent CET admissions procedure and admission rate (Lu et al., 2018), based on the differences in population, education development level, textbooks, and test papers across provinces. Moreover, the two main test categories of the CET are the nature science category and the social science category, which children choose based on their talent and interest. For the nature science category, the comprehensive subject exam assesses physics, chemistry, and biology. For the social science category, the comprehensive subject exam assesses political science, history, and geography. Except for differences in the comprehensive subjects, the test of mathematics is more difficult for 
the nature science category. In addition, the difficulty of the exam varies by years. Thus, CET performance is only comparable within the same province, test category, and test year. Correspondingly, we add full sets of fixed effects of test province, test category, and test year in the regression equations.

Our regression specification for children's performance on the CET is then:

$y_{c h}=\alpha+\beta U H D_{h}+\gamma X_{c h}+\mu_{p}+\mu_{\text {category }}+\mu_{t}+\varepsilon_{c h}$,

where $y_{c h}$ is the CET performance of child $c$ from household $h$ indicated by her/his CET score and a dummy variable for entering an elite university. Our regressor of interest, the dummy variable of $U H D_{h}$, equals 1 if child $c$ sat for the CET after her/his household $h$ experienced UHD, and equals 0 if household $h$ has never experienced UHD before the survey was conducted. Control variable $X_{c h}$ includes gender ( 1 for boys, 0 for girls) and nationality (Han or not) of child $c$ as well as family size, number of children, and education years of head of household $h$ where child $c$ is from. $\mu_{p}, \mu_{\text {category }}$, and $\mu_{t}$ are fixed effects of test province, test category, and test year, respectively. $\varepsilon_{c h}$ is the error term. Standard errors of estimated coefficients are clustered over the province level.

Unlike the CET, in which competition is restricted to the same province, the HET is usually organized at the city level and children mainly compete with peers from the same city, as investigated in Hoekstra et al. (2018). In reality, the HET and high school admission process are commonly organized at the county level in some regions as well. Therefore, for the robustness of our results, we estimate the results with city or county fixed effects. Moreover, compared with the binary choice of nature or social science category before sitting for the CET, on the HET, every child is assessed on the same subjects; thus, there is no test category fixed effect in the regression equation of HET performance.

We estimate a similar version of equation (4) as equation (5): 


$$
y_{c h}=\alpha+\beta U H D_{h}+\gamma X_{c h}+\mu_{c i t y / c o u n t y}+\mu_{t}+\varepsilon_{c h},
$$

where $y_{c h}$ is the performance on the HET of child $c$ from household $h$ measured by a dummy variable for entering a key high school. The key explanatory variable, $U H D_{h}$, is a dummy variable equal to 1 if child $c$ sat for the HET after household $h$ experienced UHD and 0 if household $h$ never experienced UHD. $\mu_{\text {city/county }}$ is the test city or county fixed effects, and $\mu_{t}$ is the test year fixed effects. Control variable $X_{c h}$ is the same as those in equation (4). $\varepsilon_{c h}$ is the error term. Standard errors of estimated coefficients are clustered over the city or county level.

However, for the cross-sectional data from the 2013 CHIP, we can no longer implement the DID approach to control for household-specific underlying characteristics, for example, parent's ability, ambition, and habit which are unobservable but could be passed to their children and thereby determine children's educational achievement. As households with relatively older houses and larger family sizes are more likely to be the target of UHD (Panel B of Table 1), controlling for other potential differences between UHD and non-UHD households is necessary. To address this concern, we conduct a placebo test by comparing the subsample who experienced UHD after sitting for the CET or HET to those who never experienced UHD. Specifically, we define a placebo variable, $U H D_{h}^{\text {placebo }}$, which is a dummy variable, 1 for those that experienced UHD after sitting for the CET or HET and 0 for those that never experienced UHD. In this specification, UHD per se can no longer affect children's performance on the CET or HET because UHD occurred after the CET or HET. Hence, we expect $U H D_{h}^{\text {placebo }}$ to cast relatively much smaller effects on the outcomes of children's educational achievement than $U H D_{h}$ in equations (4) and (5), or even zero effects. Otherwise, it indicates that the confounding factors related to UHD instead of UHD per se produce these outcomes. The regression equations of the placebo test for the performance of children on the CET and HET are similar to equations (4) and (5), except the independent variable of $U H D_{h}$ is replaced by $U H D_{h}{ }^{\text {placebo }}$. 
Furthermore, we exploit the case of Chinese UHD to examine the effects of UHD on outcomes of households, adults, and children involving various individual hypotheses. In this situation of multiple hypotheses, a true null hypothesis has a potentially large probability of being rejected, leading to false positives. To address this concern, we follow Romano and Wolf (2005a,b, 2016) to jointly test these hypotheses and produce Romano-Wolf stepdown p-values to control the family-wise error rate.

\section{Empirical findings}

The regression results are presented in detail in this section. First, the key assumption underlying the association between household wealth from UHD and children's human capital accumulation is that UHD could result in significant wealth growth for UHD households and consequently, reduce labor supply of individual adults affected by UHD. We searched for evidence in this regard in Sections 5.1 and 5.2. Second, due to the decline in labor supply of UHD individual adults, it is not necessary anymore and therefore less motivated to invest in the human capital of the adults and their children only for the promotion of competitiveness in the labor market. This would reduce UHD adults' propensity to accumulate the human capital of their children and eventually lead to lower educational achievement of children. The related evidence

is displayed in Sections 5.3 and 5.4. Third, for the panel data from the CFPS, we use individual or household fixed effects to control for the individual or household-related confounding factors. For the cross-sectional data from the 2013 CHIP, placebo tests are implemented to examine and rule out the potential effects of these confounding factors.

\subsection{Household wealth condition}

The regression results for the effect of UHD on household wealth condition are reported in Table 3. The first three regressions are performed on the full sample at the household level concerning number of houses they own, market value of those houses as evaluated by 
respondents, and their cash and bank deposits. These three dependent variables are three key dimensions of household wealth condition. All these regressions confirm the same patterns, that is, UHD increases household wealth, which is both economically large and statistically significant. More specifically, we find that UHD has a strongly positive effect on household wealth condition (with a point estimate of 0.22 for house number, 275.72 for house value, and 11.82 for cash and bank deposits all at the 1 percent level). The meanings of point estimates are that compared with non-UHD households, UHD households could have more houses $(0.22$ in number), more expensive houses (RMB 2,757,211 in value), and more cash and bank deposits (RMB 118,246 in value) after experiencing UHD. The total wealth growth resulting from UHD is RMB 2,875,457 (i.e., the increase of house value plus the increase of cash and bank deposits). Since the per capita Chinese disposable income in 2016 was only RMB 23,821, according to the National Bureau of Statistics of China, the wealth increase induced by UHD is considerable for affected households. This could be a huge shock that potentially alters household members' behavior regarding labor supply and human capital accumulation.

Table 3

Household wealth condition

\begin{tabular}{|c|c|c|c|c|c|c|c|}
\hline \multirow[t]{3}{*}{ Variables } & $\begin{array}{l}\text { House } \\
\text { number }\end{array}$ & $\begin{array}{l}\text { House value } \\
\text { (in RMB }\end{array}$ & $\begin{array}{l}\text { Cash and } \\
\text { bank }\end{array}$ & \multicolumn{2}{|c|}{$\begin{array}{l}\text { House value } \\
\text { (in RMB 10,000) }\end{array}$} & \multicolumn{2}{|c|}{$\begin{array}{l}\text { Cash and bank deposits } \\
\text { (in RMB 10,000) }\end{array}$} \\
\hline & (1) & (2) & (3) & (4) & (5) & (6) & $(7)$ \\
\hline & & Full sample & & $\begin{array}{l}\text { Bottom and } \\
\text { top } 1 \% \text { are } \\
\text { excluded. }\end{array}$ & $\begin{array}{l}\text { Bottom and } \\
\text { top 5\% are } \\
\text { excluded. }\end{array}$ & $\begin{array}{l}\text { Bottom } \\
\text { and top } \\
1 \% \text { are } \\
\text { excluded. }\end{array}$ & $\begin{array}{l}\text { Bottom } \\
\text { and top } \\
5 \% \text { are } \\
\text { excluded. }\end{array}$ \\
\hline UHD×post & $\begin{array}{l}0.2182 * * * \\
(0.0467) \\
{[0.0000]}\end{array}$ & $\begin{array}{l}275.7211 * * * \\
(54.4768) \\
{[0.0000]}\end{array}$ & $\begin{array}{l}11.8246 * * * \\
(1.2744) \\
{[0.0000]}\end{array}$ & $\begin{array}{l}27.6241 * * * \\
(8.6652) \\
{[0.0000]}\end{array}$ & $\begin{array}{l}36.7075 * * * \\
(6.5485) \\
{[0.0000]}\end{array}$ & $\begin{array}{l}7.1588 * * * \\
(1.0472) \\
{[0.0000]}\end{array}$ & $\begin{array}{l}8.9485 * * * \\
(0.7951) \\
{[0.0000]}\end{array}$ \\
\hline Family size & $\begin{array}{l}0.0902 * * * \\
(0.0072)\end{array}$ & $\begin{array}{l}10.8845 \\
(8.3189)\end{array}$ & $\begin{array}{l}0.7562 * * * \\
(0.2420)\end{array}$ & $\begin{array}{l}7.4979 * * * \\
(0.9036)\end{array}$ & $\begin{array}{l}5.2063 * * * \\
(0.7225)\end{array}$ & $\begin{array}{l}0.5245^{* * * *} \\
(0.1490)\end{array}$ & $\begin{array}{l}0.2681 * * \\
(0.1170)\end{array}$ \\
\hline $\begin{array}{l}\text { Children } \\
\text { number }\end{array}$ & $\begin{array}{l}-0.0054 \\
(0.0144)\end{array}$ & $\begin{array}{l}-5.1114 \\
(16.7526)\end{array}$ & $\begin{array}{l}-0.4403 \\
(0.4774)\end{array}$ & $\begin{array}{l}-3.2083^{*} \\
(1.7708)\end{array}$ & $\begin{array}{l}0.2556 \\
(1.4014)\end{array}$ & $\begin{array}{l}-0.0301 \\
(0.2941)\end{array}$ & $\begin{array}{l}-0.0242 \\
(0.2283)\end{array}$ \\
\hline Age & $\begin{array}{l}0.0001 \\
(0.0036)\end{array}$ & $\begin{array}{l}-2.2732 \\
(4.1590)\end{array}$ & $\begin{array}{l}-0.2653^{* *} \\
(0.1164)\end{array}$ & $\begin{array}{l}-0.0886 \\
(0.4351)\end{array}$ & $\begin{array}{l}0.1699 \\
(0.3433)\end{array}$ & $\begin{array}{l}-0.1845^{* *} \\
(0.0722)\end{array}$ & $\begin{array}{l}-0.0201 \\
(0.0573)\end{array}$ \\
\hline Squared age & $\begin{array}{l}-0.0000 \\
(0.0000)\end{array}$ & $\begin{array}{l}0.0026 \\
(0.0401)\end{array}$ & $\begin{array}{l}0.0026 * * \\
(0.0011)\end{array}$ & $\begin{array}{l}-0.0007 \\
(0.0042)\end{array}$ & $\begin{array}{l}-0.0024 \\
(0.0033)\end{array}$ & $\begin{array}{l}0.0017 * * \\
(0.0007)\end{array}$ & $\begin{array}{l}0.0001 \\
(0.0006)\end{array}$ \\
\hline
\end{tabular}




\begin{tabular}{|c|c|c|c|c|c|c|c|}
\hline $\begin{array}{l}\text { Education } \\
\text { years } \times \text { year } \\
2014\end{array}$ & $\begin{array}{l}0.0022 \\
(0.0023)\end{array}$ & $\begin{array}{l}0.8026 \\
(2.6719)\end{array}$ & $\begin{array}{l}-0.0144 \\
(0.0803)\end{array}$ & $\begin{array}{l}0.2760 \\
(0.2812)\end{array}$ & $\begin{array}{l}0.3181 \\
(0.2241)\end{array}$ & $\begin{array}{l}0.0752 \\
(0.0493)\end{array}$ & $\begin{array}{l}0.0430 \\
(0.0382)\end{array}$ \\
\hline $\begin{array}{l}\text { Education } \\
\text { years } \times \text { year } \\
2016\end{array}$ & $\begin{array}{l}0.0030 \\
(0.0022)\end{array}$ & $\begin{array}{l}0.3603 \\
(2.5667)\end{array}$ & $\begin{array}{l}0.2953 * * * \\
(0.0696)\end{array}$ & $\begin{array}{l}1.4081 * * * \\
(0.2708)\end{array}$ & $\begin{array}{l}0.9827 * * * \\
(0.2163)\end{array}$ & $\begin{array}{l}0.1994 * * * \\
(0.0431)\end{array}$ & $\begin{array}{l}0.0565 * \\
(0.0343)\end{array}$ \\
\hline $\begin{array}{l}\text { Household } \\
\text { fixed effects }\end{array}$ & Yes & Yes & Yes & Yes & Yes & Yes & Yes \\
\hline $\begin{array}{l}\text { Province- } \\
\text { year fixed } \\
\text { effects }\end{array}$ & Yes & Yes & Yes & Yes & Yes & Yes & Yes \\
\hline Observations & 13400 & 13356 & 12876 & 12935 & 11755 & 12623 & 11443 \\
\hline $\mathrm{R}^{2}$ & 0.0595 & 0.0225 & 0.0942 & 0.2598 & 0.2892 & 0.1154 & 0.1395 \\
\hline
\end{tabular}

Notes. Regressions are based on the CFPS data. Robust standard errors in parentheses are calculated by clustering over the household. Romano-Wolf stepdown p-values in square brackets are produced for multiple hypotheses of the effects of UHD. First three columns are tested jointly, columns (4) and (6) are tested jointly, and columns (5) and (7) are tested jointly. $* * *, * *$, and $*$ mean that coefficients are significant at $1 \%, 5 \%$, and $10 \%$.

However, as Ho (2013a) describes, the distribution of UHD compensation may not be equitable; thus, extreme points (i.e., outliers) would largely influence our regression results. To make our results more representative and robust, we conduct a sequence of additional regressions where potential outliers are removed. In the last four columns of Table 3, we remove a small number of households whose reported house value or cash and bank deposits are in the bottom or top $1 \%$ or $5 \%$. The same qualitative patterns are preserved, but the magnitudes of the estimated coefficients become smaller, especially for house value. However, even based on the smallest coefficients, RMB 347,829 (i.e., RMB 276,241 of house value increase in column [4] plus RMB 71,588 of cash and bank deposits increase in column [7]) is substantial wealth growth for UHD households. Afterward, this wealth growth almost equals 15 years of individual income in China. For the concern of false positives, we calculate and report the Romano-Wolf stepdown p-values of the DID interactions between $U H D$ and post in square brackets. Specifically, the regressions in the first three columns are tested jointly, columns (4) and (6) are tested jointly and columns (5) and (7) are tested jointly. Regardless of the regular p-values or Romano-Wolf stepdown p-values, all the effects of UHD on household wealth condition are highly significant.

\subsection{Individual labor supply and life satisfaction}

Since the effect of UHD on household wealth growth is clear, we then turn to the evidence of the changes in individual labor supply in the extensive margin over time and their 
relationship with UHD. It is informative about the wealth effect on labor supply to exploit the case of UHD in China, which is an ideal means to overcome the problems in the estimation of labor supply elasticities discussed in Keane (2011) and Picchio et al. (2017). In line with the illustration of Figure 2, our regression results confirm the negative effect of UHD on individual labor supply with more detailed information. Focusing on the result from the full sample, with full sets of control variables, the magnitude of the effect is -0.0377 as shown in column (1) of Table 4, which implies that if an adult is from a UHD household, she/he would have a 3.77 percentage point higher probability of giving up their job and being unemployed in the post-UHD era than non-UHD individuals.

In addition, considering the mandatory retirement age in China (60 for men and 55 for women), we further restrict the full sample to men aged 22 to 60 and women aged 22 to 55 . Based on the comparison of coefficients of DID terms shown in columns (3) and (5), we find that women are much more likely to reduce their labor supply by becoming unemployed than men after experiencing UHD (8.79 percentage points for women vs. 1.48 percentage points for men). Moreover, the effect of UHD on labor supply for men in column (3) is not significant, whereas that for women in column (5) is significant at the 5\% level. This result reveals a traditional social norm in China may work that men go outside the home to work while women work at home by performing household chores (Chen and Ge, 2018). Furthermore, it echoes the study of Fu et al. (2016), who find that wealth from housing price appreciation in China decreases women's labor supply but has little influence on that of men.

Although we could regard UHD in China as a positive event in terms of household wealth growth (Section 5.1.), some studies have depicted the misery and suffering originating from the experiences of unmaking and remaking a home (Zhang, 2018) and forced evictions (Ho, 2013b) caused by Chinese UHD. If this phenomenon is widespread, the case might be that the aforementioned misery and suffering force UHD individuals to give up their jobs instead of the 
wealth effect of UHD on labor supply. To check this possibility, we further examine whether UHD reduces individual life satisfaction, as has been described in some literature (Zhang, 2018; Ho, 2013b). Unlike the results of the field research with relatively smaller sample sizes in Zhang (2018) and Ho (2013a,b), our regression result based on the nationally large sample shows UHD, by contrast, significantly increases individual life satisfaction for the full sample in column (2) of Table 4. Columns (4) and (6) indicate women tend to have greater increases in life satisfaction than men after experiencing UHD, although the regression results are not significant. Moreover, in line with our finding, $\mathrm{Li}$ and Song (2009) document that UHD in China substantially improves housing condition and dwelling satisfaction. Therefore, this additional evidence could mitigate the concern.

Romano-Wolf stepdown p-values are also presented in square brackets. The variables in columns (1) and (2) are tested jointly, and the last four columns are tested jointly. The significance of the effects of the DID term (UHD ×post) does not change under these adjusted pvalues, which mitigates the concern of false positives.

Table 4

Individual adult labor supply and life satisfaction

\begin{tabular}{|c|c|c|c|c|c|c|}
\hline \multirow[t]{2}{*}{ Variables } & $\begin{array}{l}\text { Employed } \\
\text { (1) }\end{array}$ & $\begin{array}{l}\text { Life } \\
\text { satisfaction } \\
(2)\end{array}$ & $\begin{array}{l}\text { Employed } \\
(3)\end{array}$ & $\begin{array}{l}\text { Life } \\
\text { satisfaction } \\
(4)\end{array}$ & $\begin{array}{l}\text { Employed } \\
\text { (5) }\end{array}$ & $\begin{array}{l}\text { Life } \\
\text { satisfaction } \\
(6)\end{array}$ \\
\hline & \multicolumn{2}{|c|}{ Full sample } & \multicolumn{2}{|c|}{ Men aged 22 to 60} & \multicolumn{2}{|c|}{ Women aged 22 to 55} \\
\hline \multirow[t]{3}{*}{ UHD $\times$ post } & $-0.0377 *$ & $0.0826^{*}$ & -0.0148 & 0.0634 & $-0.0879 * *$ & 0.1371 \\
\hline & $(0.0186)$ & $(0.0520)$ & $(0.0281)$ & $(0.0918)$ & $(0.0368)$ & $(0.0936)$ \\
\hline & {$[0.0693]$} & {$[0.0990]$} & {$[0.7426]$} & {$[0.7426]$} & {$[0.0396]$} & {$[0.3762]$} \\
\hline \multirow[t]{2}{*}{ Family size } & $-0.0078 * * *$ & -0.0026 & -0.0065 & 0.0098 & -0.0080 & -0.0122 \\
\hline & $(0.0028)$ & $(0.0080)$ & $(0.0043)$ & $(0.0146)$ & $(0.0056)$ & $(0.0147)$ \\
\hline Children & $-0.0200 * * *$ & 0.0129 & 0.0023 & 0.0082 & $-0.0438 * * *$ & 0.0381 \\
\hline number & $(0.0053)$ & $(0.0150)$ & $(0.0077)$ & $(0.0257)$ & $(0.0099)$ & $(0.0255)$ \\
\hline \multirow[t]{2}{*}{ Age } & $0.1003 * * *$ & $-0.1277 * * *$ & $0.1059 * * *$ & $-0.1263^{* *}$ & $0.1253 * * *$ & $-0.1300 * *$ \\
\hline & $(0.0104)$ & $(0.0297)$ & $(0.0160)$ & $(0.0539)$ & $(0.0226)$ & $(0.0600)$ \\
\hline \multirow[t]{2}{*}{ Squared age } & $-0.0008 * * *$ & $0.0005 * * *$ & $-0.0009 * * *$ & 0.0002 & $-0.0013 * * *$ & $0.0007 * *$ \\
\hline & $(0.00003)$ & $(0.0001)$ & $(0.0001)$ & $(0.0003)$ & $(0.0001)$ & $(0.0003)$ \\
\hline Education & $0.0030 * * *$ & $-0.0047 *$ & 0.0004 & $-0.0091 *$ & 0.0028 & $-0.0136 * * *$ \\
\hline $\begin{array}{l}\text { years } \times \text { year } \\
2014\end{array}$ & $(0.0009)$ & $(0.0024)$ & $(0.0016)$ & $(0.0052)$ & $(0.0018)$ & $(0.0048)$ \\
\hline Education & 0.0003 & $-0.0092 * * *$ & -0.0019 & 0.0005 & 0.00001 & $-0.0111 * *$ \\
\hline $\begin{array}{l}\text { years } \times \text { year } \\
2016\end{array}$ & (0.0009) & $(0.0026)$ & $(0.0014)$ & $(0.0046)$ & $(0.0018)$ & $(0.0046)$ \\
\hline
\end{tabular}




\begin{tabular}{|c|c|c|c|c|c|c|}
\hline Male $\times$ year & $0.0201 * *$ & $0.0456 * *$ & & & & \\
\hline 2014 & $(0.0080)$ & $(0.0227)$ & & & & \\
\hline Male $\times$ year & 0.0078 & -0.0144 & & & & \\
\hline 2016 & $(0.0082)$ & $(0.0229)$ & & & & \\
\hline $\begin{array}{l}\text { Individual } \\
\text { fixed effects }\end{array}$ & Yes & Yes & Yes & Yes & Yes & Yes \\
\hline $\begin{array}{l}\text { Province- } \\
\text { year fixed } \\
\text { effects }\end{array}$ & Yes & Yes & Yes & Yes & Yes & Yes \\
\hline Observations & 46558 & 44294 & 16236 & 15342 & 14881 & 14310 \\
\hline $\mathrm{R}^{2}$ & 0.0473 & 0.0855 & 0.0531 & 0.1038 & 0.0440 & 0.0941 \\
\hline
\end{tabular}

Notes. Regressions are based on the CFPS data. For the variable employed, 1 is for being employed and 0 is for being unemployed. Life satisfaction is measured on a 5-point scale, 1 (strongly unsatisfied) to 5 (strongly satisfied). Robust standard errors in parentheses are calculated by clustering over the household. Romano-Wolf stepdown p-values in square brackets are produced for multiple hypotheses of the effects of UHD. The first two columns are tested jointly, and the last four columns are tested jointly. $* * *, * *$, and $*$ mean that coefficients are significant at $1 \%, 5 \%$, and $10 \%$.

\subsection{Propensity to accumulate children's human capital}

In this section, we focus on the effect of UHD on adults' propensity to accumulate their children's human capital. It is already significant in the former sections that wealth growth from UHD has a negative influence on the labor supply of adults. In this respect, a rational act is for UHD adults to reduce their propensity to invest in the human capital of their children. This hypothesis is supported by the evidence shown in Table 5. For the regression results of the full sample in columns (1) and (2), first, UHD adults spend on average relatively less weekly hours in tutoring their children for homework completion (1.88 hours less) after experiencing UHD; second, UHD adults have lower educational expectations for their children in the post-UHD era, that is, a 13.01 percentage point lower probability of expecting that their children obtain at least a bachelor's degree. Usually, Chinese children start elementary schools at age 6 or 7 years, and only after that will they have adequate homework that requires tutorship from adults. In this way, we further analyze the subsample that excludes children younger than 6 years old who may not need tutorship. The magnitude and significance of the estimated coefficient of UHD $\times$ post are much larger in column (3) than that of the full sample in column (1). The variables in columns (1)

\footnotetext{
${ }^{4}$ Moreover, there is another possibility that due to their improved ability to pay, UHD households may increase other investment on children's human capital to offset the decline in tutoring hours. But we do not find enough evidence to support this point, that is, UHD households do not significantly increase their savings for children's education.
} 
and (2) are jointly tested, and the Romano-Wolf stepdown p-values are reported in square

brackets.

Table 5

Adults' propensity to accumulate their children's human capital

\begin{tabular}{|c|c|c|c|}
\hline \multirow[t]{2}{*}{ Variables } & $\begin{array}{l}\text { Tutoring hours } \\
\text { (1) }\end{array}$ & $\begin{array}{l}\text { Educational } \\
\text { expectation } \\
\text { (2) }\end{array}$ & $\begin{array}{l}\text { Tutoring hours } \\
\text { (3) }\end{array}$ \\
\hline & \multicolumn{2}{|c|}{ Full sample } & $\begin{array}{l}\text { Children aged } \\
\text { younger than } 6 \text { years } \\
\text { are excluded. }\end{array}$ \\
\hline \multirow[t]{3}{*}{ UHD×post } & -1.8829 & $-0.1301 * *$ & $-3.3953 * *$ \\
\hline & (1.3769) & $(0.0614)$ & (1.6366) \\
\hline & {$[0.1881]$} & {$[0.0495]$} & \\
\hline \multirow[t]{2}{*}{ Family size } & $0.4153 * *$ & -0.0020 & 0.4262 \\
\hline & $(0.2089)$ & $(0.0086)$ & $(0.2797)$ \\
\hline \multirow[t]{2}{*}{ Children number } & -0.1534 & -0.0053 & -0.0073 \\
\hline & $(0.4002)$ & $(0.0172)$ & $(0.5281)$ \\
\hline \multirow[t]{2}{*}{ Adult age } & -0.1122 & $-0.0079 *$ & -0.1196 \\
\hline & $(0.0992)$ & $(0.0044)$ & $(0.1375)$ \\
\hline \multirow[t]{2}{*}{ Adult squared age } & 0.0010 & $0.0001 * *$ & 0.0010 \\
\hline & $(0.0011)$ & $(0.00005)$ & $(0.0014)$ \\
\hline \multirow[t]{2}{*}{ Child age } & 0.4002 & -0.0329 & -1.1107 \\
\hline & $(0.8959)$ & $(0.0312)$ & $(1.2365)$ \\
\hline \multirow[t]{2}{*}{ Child squared age } & $-0.1202 * * *$ & -0.0001 & $-0.0833 * * *$ \\
\hline & $(0.0158)$ & $(0.0005)$ & $(0.0245)$ \\
\hline Adult education & -0.0076 & $0.0064 * *$ & -0.0242 \\
\hline years $\times$ year 2014 & $(0.0609)$ & $(0.0027)$ & $(0.0697)$ \\
\hline Adult education & $0.1846 * * *$ & $0.0042 *$ & $0.1794 * *$ \\
\hline years $\times$ year 2016 & $(0.0598)$ & $(0.0026)$ & $(0.0726)$ \\
\hline \multirow[t]{2}{*}{ Male $\times$ year 2014} & $1.2497 * *$ & $-0.0552 * *$ & 0.8557 \\
\hline & $(0.4829)$ & $(0.0216)$ & $(0.6087)$ \\
\hline \multirow[t]{2}{*}{ Male $\times$ year 2016} & 0.1692 & -0.0140 & -0.1125 \\
\hline & $(0.5473)$ & $(0.0228)$ & $(0.6715)$ \\
\hline \multirow[t]{2}{*}{ Boy $\times$ year 2014} & 0.0444 & -0.0093 & 0.3790 \\
\hline & $(0.4864)$ & $(0.0258)$ & (0.6029) \\
\hline \multirow[t]{2}{*}{ Boy $\times$ year 2016} & 0.7687 & -0.0133 & 0.8037 \\
\hline & $(0.5576)$ & $(0.0270)$ & $(0.7404)$ \\
\hline $\begin{array}{l}\text { Individual fixed } \\
\text { effects }\end{array}$ & Yes & Yes & Yes \\
\hline $\begin{array}{l}\text { Province-year fixed } \\
\text { effects }\end{array}$ & Yes & Yes & Yes \\
\hline Observations & 4119 & 7438 & 3272 \\
\hline $\mathrm{R}^{2}$ & 0.1144 & 0.0551 & 0.1022 \\
\hline
\end{tabular}

Notes. Regressions are based on the CFPS data. For the variable of educational expectation, 1 is for expecting that their children obtain at least a bachelor's degree and 0 is for not. Robust standard errors in parentheses are calculated by clustering over the household. Romano-Wolf stepdown p-values in square brackets are produced for multiple hypotheses of the effects of UHD. First two columns are tested jointly. ***,**, and * mean that coefficients are significant at $1 \%, 5 \%$, and $10 \%$.

\subsection{Children's educational achievement}

Finally, we examine educational achievement indicators by children, namely, their performance on the CET and HET, the two most important tests in their childhood. In our 
explanation, the reduction of the propensity for adults to accumulate the human capital of their children, which is induced by UHD, could be eventually embodied in children's educational achievement. First, we look at the outcomes of CET performance. Column (1) of Table 6 relates children's CET scores to their UHD experiences and other determinants. We find that UHD experiences have a strongly negative effect on CET scores (with a point estimate of -15.33 on the dummy variable of $U H D$, which is statistically significant). This finding means that compared with children who never experienced UHD, children who experienced UHD before sitting for the CET, score 15.33 points lower. The differences in CET scores between UHD and non-UHD children are economically large. Notably, a 1-year increase in education for household heads increases CET scores by 3.63 points. The effect on the probability of entering elite universities presents the same pattern. The parameter estimate of -0.0956 in column (2) implies that UHD experiences reduce the probability of entering elite universities by 9.56 percentage points. By comparison, a 1-year increase in household heads' education only increases this probability by 1.53 percentage points, indicating the economic significance of UHD experiences' effect.

Concerned by the noise from possible outliers, we further conduct additional regressions in which observations with extreme CET scores are removed through three different filters. In columns (3) and (4), we take out a small number of children whose reported CET scores are in the bottom or top $1 \%$. In columns (5) and (6), observations with bottom or top 5\% CET scores are excluded. Additionally, we remove the observations with CET scores lower than 200 points or higher than 700 points, scores that seem too low or too high to be realistic, possibly owing to misreporting by respondents. In all cases, we observe the same patterns: UHD experiences before CET significantly decrease CET performance of children including their CET scores and the probability of entering elite universities. In fact, the point estimate of UHD experiences and its significance are moderately larger for the cases without possible outliers. The variables of 
columns (1) and (2) are jointly tested, and the same for columns (3) and (4), columns (5) and (6), and columns (7) and (8). The Romano-Wolf stepdown p-values are reported in square brackets.

Second, we turn to the outcomes of HET performance. In particular, we examine the differences in the probability of entering key high schools, which is a reasonable indicator of HET performance. Table 7 displays the regression results. In column (1), under the assumption of sitting for the HET at age 15 years and with HET city fixed effects, children who experienced UHD before sitting for the HET exhibit a 13.89 percentage point lower probability of entering key high schools, compared with those who never experienced UHD ${ }^{5}$. Considering that children may sit for the HET at different ages and that the HET may be organized at the county level, for the robustness of our results, we also provide the regression results under the assumption of sitting for the HET at age 16 and 17 years and with county fixed effects. We consistently find the same patterns in all cases. These results suggest not only the CET but also the HET performance of children is significantly and negatively affected by UHD experiences.

Third, the data from the 2013 CHIP used in this section is only cross-sectional; thus, we are unable to add household or children fixed effects to control for more confounding factors as we do in the former sections. We conduct placebo tests to verify further whether the differences in children's educational achievement are affected by UHD experiences or only by UHD-related confounding factors. More specifically, we use a placebo variable of UHD experiences, $U H D_{h}^{\text {placebo }}$, in which we define children who experienced UHD after sitting for the CET or HET as our treatment group instead. Table 8 and 9 show the regression results of these placebo tests. As we expect, all coefficients of $U H D_{h}^{\text {placebo }}$ are statistically insignificant, and the magnitudes are

\footnotetext{
${ }^{5}$ We propose UHD children's relatively lower performance in CET and HET are driven by the decline in their parents' propensity to accumulate children's human capital. But it also may be the case that children in UHD family become less willing to study hard due to the improved family wealth after UHD. We find this impact exists, but is not statistically significant by doing additional regressions. Because the CFPS data we employ only covers a short period of time, insignificant impact in the short term may become significant over the long term. This issue can be explored in future research. But at present, we do not have strong evidence to support this proposition.
} 
relatively much smaller, for example, -15.33 in column (1) of Table 6 versus -1.13 in column (1) of Table 8. These results of the placebo tests could lend further support to our explanation, in which household wealth growth from UHD has a detrimental influence on children's human capital accumulation. 
Table 6

CET performance of children

\begin{tabular}{|c|c|c|c|c|c|c|c|c|}
\hline \multirow[t]{2}{*}{ Variables } & $\begin{array}{l}\text { CET scores } \\
\text { (1) } \\
\end{array}$ & $\begin{array}{l}\text { Elite } \\
\text { universities } \\
(2)\end{array}$ & $\begin{array}{l}\text { CET scores } \\
\text { (3) } \\
\end{array}$ & $\begin{array}{l}\text { Elite } \\
\text { universities } \\
(4) \\
\end{array}$ & $\begin{array}{l}\text { CET scores } \\
(5) \\
\end{array}$ & $\begin{array}{l}\text { Elite } \\
\text { universities } \\
(6)\end{array}$ & $\begin{array}{l}\text { CET scores } \\
(7) \\
\end{array}$ & $\begin{array}{l}\text { Elite } \\
\text { universities } \\
(8)\end{array}$ \\
\hline & \multicolumn{2}{|l|}{ Full sample } & \multicolumn{2}{|c|}{$\begin{array}{l}\text { Bottom and top 1\% CET } \\
\text { scores are excluded. }\end{array}$} & \multicolumn{2}{|c|}{$\begin{array}{l}\text { Bottom and top 5\% CET } \\
\text { scores are excluded. }\end{array}$} & \multicolumn{2}{|c|}{$\begin{array}{l}\text { CET scores higher than } 700 \\
\text { and lower } 200 \text { are excluded }\end{array}$} \\
\hline UHD & $\begin{array}{l}-15.3257 * \\
(9.1094) \\
{[0.0891]}\end{array}$ & $\begin{array}{l}-0.0956 * * \\
(0.0426) \\
{[0.0396]}\end{array}$ & $\begin{array}{l}-19.1524 * * \\
(8.6038) \\
{[0.0297]}\end{array}$ & $\begin{array}{l}-0.1049 * * \\
(0.0431) \\
{[0.0198]}\end{array}$ & $\begin{array}{l}-22.6201 * * * \\
(7.7201) \\
{[0.0099]}\end{array}$ & $\begin{array}{l}-0.1015 * * \\
(0.0434) \\
{[0.0198]}\end{array}$ & $\begin{array}{l}-17.1062 * * \\
(8.7821) \\
{[0.0495]}\end{array}$ & $\begin{array}{l}-0.0972 * * \\
(0.0428) \\
{[0.0396]}\end{array}$ \\
\hline Family size & $\begin{array}{l}-1.7659 \\
(3.2978)\end{array}$ & $\begin{array}{l}-0.0136 \\
(0.0157)\end{array}$ & $\begin{array}{l}-1.7471 \\
(3.0898)\end{array}$ & $\begin{array}{l}-0.0111 \\
(0.0157)\end{array}$ & $\begin{array}{l}-3.3087 \\
(2.7637)\end{array}$ & $\begin{array}{l}-0.0138 \\
(0.0157)\end{array}$ & $\begin{array}{l}-0.7372 \\
(3.1808)\end{array}$ & $\begin{array}{l}-0.0127 \\
(0.0159)\end{array}$ \\
\hline $\begin{array}{l}\text { Children } \\
\text { number }\end{array}$ & $\begin{array}{l}-3.8765 \\
(3.8765)\end{array}$ & $\begin{array}{l}0.0260 \\
(0.0187)\end{array}$ & $\begin{array}{l}-3.4205 \\
(3.6227)\end{array}$ & $\begin{array}{l}0.0262 \\
(0.0187)\end{array}$ & $\begin{array}{l}-0.8392 \\
(3.2294)\end{array}$ & $\begin{array}{l}0.0335^{*} \\
(0.0185)\end{array}$ & $\begin{array}{l}-4.6464 \\
(3.7271)\end{array}$ & $\begin{array}{l}0.0260 \\
(0.0188)\end{array}$ \\
\hline $\begin{array}{l}\text { Nationality } \\
\text { (Han or not) }\end{array}$ & $\begin{array}{l}4.7169 \\
(10.7662)\end{array}$ & $\begin{array}{l}0.0321 \\
(0.0510)\end{array}$ & $\begin{array}{l}-0.7977 \\
(10.0388)\end{array}$ & $\begin{array}{l}0.0244 \\
(0.0509)\end{array}$ & $\begin{array}{l}-1.8629 \\
(8.7624)\end{array}$ & $\begin{array}{l}0.0114 \\
(0.0494)\end{array}$ & $\begin{array}{l}0.0303 \\
(10.4020)\end{array}$ & $\begin{array}{l}0.0282 \\
(0.0515)\end{array}$ \\
\hline $\begin{array}{l}\text { Gender (boy or } \\
\text { not) }\end{array}$ & $\begin{array}{l}-8.2489 \\
(5.0445)\end{array}$ & $\begin{array}{l}-0.0124 \\
(0.0234)\end{array}$ & $\begin{array}{l}-10.1476 * * \\
(4.7280)\end{array}$ & $\begin{array}{l}-0.0187 \\
(0.0234)\end{array}$ & $\begin{array}{l}-9.7889 * * \\
(4.2566)\end{array}$ & $\begin{array}{l}-0.0234 \\
(0.0236)\end{array}$ & $\begin{array}{l}-8.5977 * \\
(4.8574)\end{array}$ & $\begin{array}{l}-0.0111 \\
(0.0235)\end{array}$ \\
\hline $\begin{array}{l}\text { Education } \\
\text { years of } \\
\text { household } \\
\text { heads }\end{array}$ & $\begin{array}{l}3.6250 * * * \\
(0.8854)\end{array}$ & $\begin{array}{l}0.0153 * * * \\
(0.0041)\end{array}$ & $\begin{array}{l}3.5037 * * * \\
(0.8276)\end{array}$ & $\begin{array}{l}0.0152 * * * \\
(0.0041)\end{array}$ & $\begin{array}{l}2.5992 * * * \\
(0.7561)\end{array}$ & $\begin{array}{l}0.0153 * * * \\
(0.0042)\end{array}$ & $\begin{array}{l}3.6547 * * * \\
(0.8515)\end{array}$ & $\begin{array}{l}0.0153 * * * \\
(0.0041)\end{array}$ \\
\hline $\begin{array}{l}\text { CET year fixed } \\
\text { effects }\end{array}$ & Yes & Yes & Yes & Yes & Yes & Yes & Yes & Yes \\
\hline $\begin{array}{l}\text { CET category } \\
\text { fixed effects }\end{array}$ & Yes & Yes & Yes & Yes & Yes & Yes & Yes & Yes \\
\hline $\begin{array}{l}\text { CET province } \\
\text { fixed effects }\end{array}$ & Yes & Yes & Yes & Yes & Yes & Yes & Yes & Yes \\
\hline Observations & 1321 & 1140 & 1290 & 1120 & 1179 & 1031 & 1312 & 1135 \\
\hline $\mathrm{R}^{2}$ & 0.1866 & 0.0852 & 0.1786 & 0.0825 & 0.1698 & 0.0864 & 0.1849 & 0.0859 \\
\hline
\end{tabular}

Notes. Regressions are based on the 2013 CHIP data. For the variable of elite universities, 1 is for entering elite universities and 0 is for not. UHD is 1 for those who experienced

UHD before sitting for the CET and 0 for those who never experienced UHD. Robust standard errors in parentheses are calculated by clustering over the province. Romano-Wolf stepdown p-values in square brackets are produced for multiple hypotheses of the effects of UHD. The variables of columns (1) and (2) are jointly tested, and the same for columns (3) and (4), columns (5) and (6), and columns (7) and (8).***,**, and * mean that coefficients are significant at $1 \%, 5 \%$, and $10 \%$. 
Table 7

HET performance of children

\begin{tabular}{|c|c|c|c|c|c|c|}
\hline \multirow[t]{3}{*}{ Variables } & \multicolumn{6}{|c|}{ Key high schools } \\
\hline & $(1)$ & $(2)$ & (3) & $(4)$ & $(5)$ & $(6)$ \\
\hline & \multicolumn{2}{|c|}{$\begin{array}{l}\text { Assumption of sitting for the } \\
\text { HET at age } 15 \text { years }\end{array}$} & \multicolumn{2}{|c|}{$\begin{array}{l}\text { Assumption of sitting for the } \\
\text { HET at age } 16 \text { years }\end{array}$} & \multicolumn{2}{|c|}{$\begin{array}{l}\text { Assumption of sitting for the } \\
\text { HET at age } 17 \text { years }\end{array}$} \\
\hline UHD & $\begin{array}{l}-0.1389 * * * \\
(0.0405)\end{array}$ & $\begin{array}{l}-0.1370 * * * \\
(0.0373)\end{array}$ & $\begin{array}{l}-0.1332 * * * \\
(0.0412)\end{array}$ & $\begin{array}{l}-0.1325 * * * \\
(0.0370)\end{array}$ & $\begin{array}{l}-0.1311 * * * \\
(0.0435)\end{array}$ & $\begin{array}{l}-0.1301 * * * \\
(0.0375)\end{array}$ \\
\hline Family size & $\begin{array}{l}-0.0025 \\
(0.0122)\end{array}$ & $\begin{array}{l}-0.0069 \\
(0.0123)\end{array}$ & $\begin{array}{l}-0.0013 \\
(0.0122)\end{array}$ & $\begin{array}{l}-0.0061 \\
(0.0123)\end{array}$ & $\begin{array}{l}-0.0014 \\
(0.0122)\end{array}$ & $\begin{array}{l}-0.0060 \\
(0.0123)\end{array}$ \\
\hline $\begin{array}{l}\text { Children } \\
\text { number }\end{array}$ & $\begin{array}{l}-0.0091 \\
(0.0156)\end{array}$ & $\begin{array}{l}-0.0066 \\
(0.0150)\end{array}$ & $\begin{array}{l}-0.0095 \\
(0.0156)\end{array}$ & $\begin{array}{l}-0.0071 \\
(0.0151)\end{array}$ & $\begin{array}{l}-0.0094 \\
(0.0155)\end{array}$ & $\begin{array}{l}-0.0064 \\
(0.0150)\end{array}$ \\
\hline $\begin{array}{l}\text { Nationality } \\
\text { (Han or not) }\end{array}$ & $\begin{array}{l}-0.0416 \\
(0.0561)\end{array}$ & $\begin{array}{l}-0.0566 \\
(0.0597)\end{array}$ & $\begin{array}{l}-0.0388 \\
(0.0566)\end{array}$ & $\begin{array}{l}-0.0558 \\
(0.0592)\end{array}$ & $\begin{array}{l}-0.0394 \\
(0.0566)\end{array}$ & $\begin{array}{l}-0.0561 \\
(0.0592)\end{array}$ \\
\hline $\begin{array}{l}\text { Gender (boy or } \\
\text { not) }\end{array}$ & $\begin{array}{l}-0.0519 * * \\
(0.0205)\end{array}$ & $\begin{array}{l}-0.0503 * * \\
(0.0213)\end{array}$ & $\begin{array}{l}-0.0506 * * \\
(0.0207)\end{array}$ & $\begin{array}{l}-0.0496^{* *} \\
(0.0213)\end{array}$ & $\begin{array}{l}-0.0519 * * \\
(0.0207)\end{array}$ & $\begin{array}{l}-0.0503 * * \\
(0.0212)\end{array}$ \\
\hline $\begin{array}{l}\text { Education } \\
\text { years of } \\
\text { household } \\
\text { heads }\end{array}$ & $\begin{array}{l}0.0337 * * * \\
(0.0042)\end{array}$ & $\begin{array}{l}0.0319 * * * \\
(0.0043)\end{array}$ & $\begin{array}{l}0.0337 * * * \\
(0.0042)\end{array}$ & $\begin{array}{l}0.0320 * * * \\
(0.0043)\end{array}$ & $\begin{array}{l}0.0336 * * * \\
(0.0042)\end{array}$ & $\begin{array}{l}0.0320 * * * \\
(0.0043)\end{array}$ \\
\hline $\begin{array}{l}\text { HET year fixed } \\
\text { effects }\end{array}$ & Yes & Yes & Yes & Yes & Yes & Yes \\
\hline $\begin{array}{l}\text { HET city fixed } \\
\text { effects }\end{array}$ & Yes & No & Yes & No & Yes & No \\
\hline $\begin{array}{l}\text { HET county } \\
\text { fixed effects }\end{array}$ & No & Yes & No & Yes & No & Yes \\
\hline Observations & 2391 & 2390 & 2406 & 2405 & 2422 & 2420 \\
\hline $\mathrm{R}^{2}$ & 0.1915 & 0.2519 & 0.1906 & 0.2515 & 0.1915 & 0.2522 \\
\hline
\end{tabular}

Notes. Regressions are based on the 2013 CHIP data. For the variable of key high schools, 1 is for entering key high schools and 0 is for not. UHD is 1 for those who experienced UHD before sitting for the HET and 0 for those who never experienced UHD. Robust standard errors in parentheses are calculated by clustering over the city in columns (1), (3), and (5) and clustering over the county in columns (2), (4), and (6).***,**, and * mean that coefficients are significant at $1 \%, 5 \%$, and $10 \%$. 


\section{Table 8}

Placebo tests (CET performance of children)

\begin{tabular}{|c|c|c|c|c|c|c|c|c|}
\hline \multirow[t]{2}{*}{ Variables } & $\begin{array}{l}\text { CET scores } \\
\text { (1) } \\
\end{array}$ & $\begin{array}{l}\text { Elite } \\
\text { universities } \\
(2) \\
\end{array}$ & $\begin{array}{l}\text { CET } \\
\text { scores } \\
(3) \\
\end{array}$ & $\begin{array}{l}\text { Elite } \\
\text { universities } \\
(4) \\
\end{array}$ & $\begin{array}{l}\text { CET } \\
\text { scores } \\
(5) \\
\end{array}$ & $\begin{array}{l}\text { Elite } \\
\text { universities } \\
(6) \\
\end{array}$ & $\begin{array}{l}\text { CET } \\
\text { scores } \\
(7) \\
\end{array}$ & $\begin{array}{l}\text { Elite } \\
\text { universities } \\
(8)\end{array}$ \\
\hline & \multicolumn{2}{|l|}{ Full sample } & \multicolumn{2}{|c|}{$\begin{array}{l}\text { Bottom and top 1\% CET } \\
\text { scores are excluded. }\end{array}$} & \multicolumn{2}{|c|}{$\begin{array}{l}\text { Bottom and top 5\% CET } \\
\text { scores are excluded. }\end{array}$} & \multicolumn{2}{|c|}{$\begin{array}{l}\text { CET scores higher than } \\
700 \text { and lower } 200 \text { are } \\
\text { excluded. }\end{array}$} \\
\hline UHD_placebo & $\begin{array}{l}-1.1335 \\
(14.3015) \\
{[0.9505]}\end{array}$ & $\begin{array}{l}-0.0202 \\
(0.0700) \\
{[0.9505]}\end{array}$ & $\begin{array}{l}2.3037 \\
(13.2440) \\
{[0.9802]}\end{array}$ & $\begin{array}{l}-0.0134 \\
(0.0704) \\
{[0.9802]}\end{array}$ & $\begin{array}{l}2.6409 \\
(11.9599) \\
{[0.9604]}\end{array}$ & $\begin{array}{l}0.0128 \\
(0.0731) \\
{[0.9604]}\end{array}$ & $\begin{array}{l}4.1269 \\
(13.6979) \\
{[0.9406]}\end{array}$ & $\begin{array}{l}-0.0137 \\
(0.0711) \\
{[0.9406]}\end{array}$ \\
\hline Family size & $\begin{array}{l}-0.1497 \\
(3.3719)\end{array}$ & $\begin{array}{l}-0.0027 \\
(0.0162)\end{array}$ & $\begin{array}{l}-0.7830 \\
(3.1186)\end{array}$ & $\begin{array}{l}-0.0007 \\
(0.0162)\end{array}$ & $\begin{array}{l}-3.1281 \\
(2.7881)\end{array}$ & $\begin{array}{l}-0.0055 \\
(0.0163)\end{array}$ & $\begin{array}{l}0.0066 \\
(3.2059)\end{array}$ & $\begin{array}{l}-0.0023 \\
(0.0163)\end{array}$ \\
\hline $\begin{array}{l}\text { Children } \\
\text { number }\end{array}$ & $\begin{array}{l}-4.8305 \\
(4.0070)\end{array}$ & $\begin{array}{l}0.0250 \\
(0.0194)\end{array}$ & $\begin{array}{l}-3.9972 \\
(3.7008)\end{array}$ & $\begin{array}{l}0.0252 \\
(0.0194)\end{array}$ & $\begin{array}{l}-1.1900 \\
(3.2952)\end{array}$ & $\begin{array}{l}0.0318 \\
(0.0194)\end{array}$ & $\begin{array}{l}-5.2411 \\
(3.8015)\end{array}$ & $\begin{array}{l}0.0252 \\
(0.0195)\end{array}$ \\
\hline $\begin{array}{l}\text { Nationality } \\
\text { (Han or not) }\end{array}$ & $\begin{array}{l}8.8024 \\
(11.2089)\end{array}$ & $\begin{array}{l}0.0478 \\
(0.0529)\end{array}$ & $\begin{array}{l}2.9593 \\
(10.3378)\end{array}$ & $\begin{array}{l}0.0387 \\
(0.0529)\end{array}$ & $\begin{array}{l}1.9491 \\
(8.9956)\end{array}$ & $\begin{array}{l}0.0267 \\
(0.0516)\end{array}$ & $\begin{array}{l}3.5059 \\
(10.6967)\end{array}$ & $\begin{array}{l}0.0434 \\
(0.0535)\end{array}$ \\
\hline $\begin{array}{l}\text { Gender (boy or } \\
\text { not) }\end{array}$ & $\begin{array}{l}-4.0489 \\
(5.2543)\end{array}$ & $\begin{array}{l}-0.0211 \\
(0.0245)\end{array}$ & $\begin{array}{l}-8.3197 * \\
(4.8703)\end{array}$ & $\begin{array}{l}-0.0275 \\
(0.0244)\end{array}$ & $\begin{array}{l}-8.3736^{*} \\
(4.3625)\end{array}$ & $\begin{array}{l}-0.0306 \\
(0.0248)\end{array}$ & $\begin{array}{l}-6.4148 \\
(5.0006)\end{array}$ & $\begin{array}{l}-0.0206 \\
(0.0246)\end{array}$ \\
\hline $\begin{array}{l}\text { Education } \\
\text { years of } \\
\text { household } \\
\text { heads }\end{array}$ & $\begin{array}{l}3.6075^{* * * *} \\
(0.9107)\end{array}$ & $\begin{array}{l}0.0146 * * * \\
(0.0042)\end{array}$ & $\begin{array}{l}3.4813 * * * \\
(0.8412)\end{array}$ & $\begin{array}{l}0.0146 * * * \\
(0.0042)\end{array}$ & $\begin{array}{l}2.5480 * * * \\
(0.7599)\end{array}$ & $\begin{array}{l}0.0138 * * * \\
(0.0043)\end{array}$ & $\begin{array}{l}3.5974 * * * \\
(0.8647)\end{array}$ & $\begin{array}{l}0.0145 * * * \\
(0.0043)\end{array}$ \\
\hline $\begin{array}{l}\text { CET year fixed } \\
\text { effects }\end{array}$ & Yes & Yes & Yes & Yes & Yes & Yes & Yes & Yes \\
\hline $\begin{array}{l}\text { CET category } \\
\text { fixed effects }\end{array}$ & Yes & Yes & Yes & Yes & Yes & Yes & Yes & Yes \\
\hline $\begin{array}{l}\text { CET province } \\
\text { fixed effects }\end{array}$ & Yes & Yes & Yes & Yes & Yes & Yes & Yes & Yes \\
\hline Observations & 1259 & 1084 & 1231 & 1067 & 1124 & 981 & 1250 & 1079 \\
\hline $\mathrm{R}^{2}$ & 0.1801 & 0.0849 & 0.1789 & 0.0827 & 0.1697 & 0.0845 & 0.1853 & 0.0860 \\
\hline
\end{tabular}

Notes. Regressions are based on the 2013 CHIP data. For the variable of elite universities, 1 is for entering elite universities and 0 is for not. UHD ${ }_{h}^{\text {placebo }}$ is 1 for those who experienced UHD after sitting for the CET and 0 for those who never experienced UHD. Robust standard errors in parentheses are calculated by clustering over the province. Romano-Wolf stepdown p-values in square brackets are produced for multiple hypotheses of the effects of UHD. The variables of columns (1) and (2) are jointly tested, and the same for columns (3) and (4), columns (5) and (6), and columns (7) and (8).***,**, and * mean that coefficients are significant at $1 \%, 5 \%$, and $10 \%$. 


\section{Table 9}

Placebo tests (HET performance of children)

\begin{tabular}{|c|c|c|c|c|c|c|}
\hline \multirow[t]{3}{*}{ Variables } & \multicolumn{6}{|c|}{ Key high schools } \\
\hline & (1) & $(2)$ & (3) & (4) & (5) & (6) \\
\hline & \multicolumn{2}{|c|}{$\begin{array}{l}\text { Assumption of sitting for the } \\
\text { HET at age } 15 \text { years }\end{array}$} & \multicolumn{2}{|c|}{$\begin{array}{l}\text { Assumption of sitting for the } \\
\text { HET at age } 16 \text { years }\end{array}$} & \multicolumn{2}{|c|}{$\begin{array}{l}\text { Assumption of sitting for the } \\
\text { HET at age } 17 \text { years }\end{array}$} \\
\hline UHD_placebo & $\begin{array}{l}-0.0580 \\
(0.0494)\end{array}$ & $\begin{array}{l}-0.0462 \\
(0.0512)\end{array}$ & $\begin{array}{l}-0.0613 \\
(0.0480)\end{array}$ & $\begin{array}{l}-0.0456 \\
(0.0508)\end{array}$ & $\begin{array}{l}-0.0559 \\
(0.0458)\end{array}$ & $\begin{array}{l}-0.0379 \\
(0.0543)\end{array}$ \\
\hline Family size & $\begin{array}{l}-0.0004 \\
(0.0132)\end{array}$ & $\begin{array}{l}-0.0048 \\
(0.0133)\end{array}$ & $\begin{array}{l}-0.0011 \\
(0.0131)\end{array}$ & $\begin{array}{l}-0.0055 \\
(0.0131)\end{array}$ & $\begin{array}{l}-0.0010 \\
(0.0131)\end{array}$ & $\begin{array}{l}-0.0056 \\
(0.0130)\end{array}$ \\
\hline $\begin{array}{l}\text { Children } \\
\text { number }\end{array}$ & $\begin{array}{l}-0.0085 \\
(0.0166)\end{array}$ & $\begin{array}{l}-0.0052 \\
(0.0150)\end{array}$ & $\begin{array}{l}-0.0084 \\
(0.0167)\end{array}$ & $\begin{array}{l}-0.0049 \\
(0.0151)\end{array}$ & $\begin{array}{l}-0.0086 \\
(0.0169)\end{array}$ & $\begin{array}{l}-0.0054 \\
(0.0151)\end{array}$ \\
\hline Nationality & -0.0223 & -0.0287 & -0.0233 & -0.0294 & -0.0227 & -0.0280 \\
\hline (Han or not) & $(0.0558)$ & $(0.0571)$ & $(0.0559)$ & $(0.0573)$ & $(0.0557)$ & $(0.0572)$ \\
\hline $\begin{array}{l}\text { Gender (boy or } \\
\text { not) }\end{array}$ & $\begin{array}{l}-0.0602 * * * \\
(0.0219)\end{array}$ & $\begin{array}{l}-0.0564 * * \\
(0.0222)\end{array}$ & $\begin{array}{l}-0.0609 * * * \\
(0.0218)\end{array}$ & $\begin{array}{l}-0.0566^{* *} \\
(0.0225)\end{array}$ & $\begin{array}{l}-0.0601 * * * \\
(0.0217)\end{array}$ & $\begin{array}{l}-0.0563 * * \\
(0.0225)\end{array}$ \\
\hline $\begin{array}{l}\text { Education } \\
\text { years of } \\
\text { household } \\
\text { heads }\end{array}$ & $\begin{array}{l}0.0342 * * * \\
(0.0043)\end{array}$ & $\begin{array}{l}0.0323 * * * \\
(0.0044)\end{array}$ & $\begin{array}{l}0.0341 * * * \\
(0.0043)\end{array}$ & $\begin{array}{l}0.0322 * * * \\
(0.0044)\end{array}$ & $\begin{array}{l}0.0342 * * * \\
(0.0043)\end{array}$ & $\begin{array}{l}0.0321 * * * \\
(0.0045)\end{array}$ \\
\hline $\begin{array}{l}\text { HET year fixed } \\
\text { effects }\end{array}$ & Yes & Yes & Yes & Yes & Yes & Yes \\
\hline $\begin{array}{l}\text { HET city fixed } \\
\text { effects }\end{array}$ & Yes & No & Yes & No & Yes & No \\
\hline $\begin{array}{l}\text { HET county } \\
\text { fixed effects }\end{array}$ & No & Yes & No & Yes & No & Yes \\
\hline Observations & 2336 & 2334 & 2321 & 2319 & 2305 & 2303 \\
\hline $\mathrm{R}^{2}$ & 0.2010 & 0.2620 & 0.2009 & 0.2616 & 0.1998 & 0.2609 \\
\hline
\end{tabular}

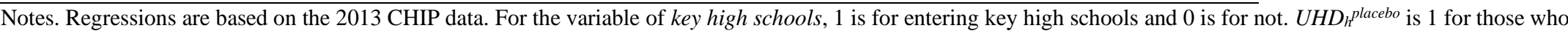
experienced UHD after sitting for the HET and 0 for those who never experienced UHD. Robust standard errors in parentheses are calculated by clustering over the city in columns (1), (3), and (5) and clustering over the county in columns (2), (4), and (6).***,**, and * mean that coefficients are significant at $1 \%, 5 \%$, and $10 \%$. 


\section{Conclusion}

The case of UHD in China provides a unique opportunity to assess the impact of household wealth growth on children's human capital again by following the seminal research by Bleakley and Ferrie (2016) and Cesarini et al. (2016). To address this issue, we use the empirical setup of the differences in whether households (i.e., individuals from those households) experienced UHD. Thanks to the real estate boom, the considerable economic compensation from UHD is probably the best chance for ordinary Chinese households to obtain such substantial wealth growth. Therefore, the scope of the study of wealth effects in China is defined.

Our data reveal that the household wealth growth induced by UHD is as much as 15 years of Chinese individual income, and consequently, reduces individual labor supply. Compared with non-UHD individuals, the probability of being employed for UHD individuals would decrease by 3.77 percentage points in the post-UHD era, especially for women (8.79 percentage points for women vs. 1.48 percentage points for men). Accompanying the decline in labor supply, adults' propensity to invest in their children's human capital correspondingly decreases in tutoring hours and educational expectations for their children after experiencing UHD, as we predict in our explanation. Eventually, the educational achievement of the UHD children who experienced UHD before their CET or HET is relatively lower than non-UHD children, who never experienced UHD. More specifically, UHD children have CET scores approximately 20 points lower, are ten percentage points less likely to enter elite universities, and are 13 percentage points less likely to enter key high schools.

Our study mainly contributes to further understanding the surprising finding of Bleakley and Ferrie (2016) and Cesarini et al. (2016), in which substantial wealth growth from winning a lottery has negative but not very significant influences on children's human capital accumulation. This "shocking behavior" (Bleakley and Ferrie, 2016) inspires us to explore again the association 
between wealth growth and human capital despite the abundant literature documenting the positive association (Filmer and Schady, 2011; Lovenheim, 2011; Dahl and Lochner, 2012). Our results suggest it is rational for individuals to reduce human capital accumulation when their labor supply is decreased by substantial wealth growth since labor earnings and human capital are probably no longer the primary. It would be of interest to further examine the wealth effects on human capital aside from the only perspective of relaxing economic constraints for education. The side effects of wealth should arouse more research attention.

Our study also provides a diverse perspective to evaluate real estate development in China given that China has faced a critical dilemma in its housing policy (Yao et al., 2014). On the one hand, real estate development plays a significant role in promoting China's economic growth and mitigating local governments' fiscal deficits (Pan et al., 2015); on the other hand, except for the argument about the housing bubble (Glaeser et al., 2017; Mao and Shen, 2019), some empirical findings regarding the consequences of soaring housing prices ( $\mathrm{Li}$ and $\mathrm{Wu}, 2014$; Chen et al., 2018; Wrenn et al., 2019) have evoked strong concern that the future success of China's economy would be undermined by the persistent real estate boom. Our results imply that the widespread UHD behind the real estate development in China could aggravate this problem, owing to the decline in labor supply and human capital accumulation induced by UHD, which are two key factors in economic development.

Finally, our results should be interpreted with some limitations in mind. First, as Hällsten and Pfeffer (2017) stress, exogenous wealth growth differs from other types of wealth growth such as family accumulated wealth. Hence, caution should be used regarding generalization of our findings to other situations, for example, household wealth growth due to increased income. Second, the UHD information, household wealth condition, working status, adults' propensity to accumulate their children's human capital, and children's education performance are all self- 
reported, which may bias the results. We suggest that future research measure all these variables

with administrative data and check the robustness of our findings.

\section{Reference}

Becker, G. S., Tomes, N., 1986. Human capital and the rise and fall of families. Journal of Labor Economics 4(3, Part 2), S1-S39.

Bleakley, H., Ferrie, J., 2016. Shocking behavior: Random wealth in antebellum Georgia and human capital across generations. Quarterly Journal of Economics 131(3), $1455-1495$.

Cai, D., Song, Q., Ma, S., Dong, Y., Xu, Q., 2018. The relationship between credit constraints and household entrepreneurship in China. International Review of Economics \& Finance 58, 246-258.

Case, A., Hosegood, V., Lund, F., 2005. The reach and impact of Child Support Grants: Evidence from KwaZulu-Natal. Development Southern Africa 22(4), 467-482.

Cesarini, D., Lindqvist, E., Notowidigdo, M. J., Östling, R., 2017. The effect of wealth on individual and household labor supply: Evidence from Swedish lotteries. American Economic Review 107(12), 3917-46.

Cesarini, D., Lindqvist, E., Östling, R., Wallace, B., 2016. Wealth, health, and child development: Evidence from administrative data on Swedish lottery players. Quarterly Journal of Economics 131(2), 687-738.

Chen, J., Hu, M., Lin, Z., 2018. Does housing unaffordability crowd out elites in Chinese superstar cities? Journal of Housing Economics, in press.

Chen, X., Ge, S., 2018. Social norms and female labor force participation in urban China. Journal of Comparative Economics 46(4), 966-987.

Cui, Y., Meng, J., Lu, C., 2018. Recent developments in China's labor market: Labor shortage, rising wages and their implications. Review of Development Economics 22(3), 1217-1238.

Dahl, G. B., Lochner, L., 2012. The impact of family income on child achievement: Evidence from the earned income tax credit. American Economic Review 102(5), 1927-56.

Day, J., Cervero, R., 2010. Effects of residential relocation on household and commuting expenditures in Shanghai, China. International Journal of Urban and Regional Research 34(4), 762-788.

De Janvry, A., Finan, F., Sadoulet, E., Vakis, R., 2006. Can conditional cash transfer programs serve as safety nets in keeping children at school and from working when exposed to shocks? Journal of Development Economics 79(2), 349-373.

Fang, L., Tian, C., 2018. Housing and marital matching: A signaling perspective. China Economic Review 47, 27-46. 
Filmer, D., Schady, N., 2011. Does more cash in conditional cash transfer programs always lead to larger impacts on school attendance? Journal of Development Economics 96(1), 150-157.

Fu, S., Liao, Y., Zhang, J., 2016. The effect of housing wealth on labor force participation: Evidence from China. Journal of Housing Economics 33, 59-69.

Glaeser, E., Huang, W., Ma, Y., Shleifer, A., 2017. A real estate boom with Chinese characteristics. Journal of Economic Perspectives 31(1), 93-116.

Hällsten, M., Pfeffer, F. T., 2017. Grand advantage: Family wealth and grandchildren's educational achievement in Sweden. American Sociological Review 82(2), 328360 .

Ho, C. Y., 2013a. Bargaining demolition in China: A practice of distrust. Critique of Anthropology 33(4), 412-428.

Ho, C. Y., 2013b. Exit, or evict: Re-grounding rights in needs in China's urban housing demolition. Asian Anthropology 12(2), 141-155.

Hoekstra, M., Mouganie, P., Wang, Y., 2018. Peer quality and the academic benefits to attending better schools. Journal of Labor Economics 36(4), 841-884.

Jia, R., Li, H., 2016. Access to elite education, wage premium, and social mobility: The truth and illusion of China's College Entrance Exam. Working Paper No. 577. Stanford Center for International Development.

Keane, M. P., 2011. Labor supply and taxes: A survey. Journal of Economic Literature 49(4), 961-1075.

Li, F., Xiao, J. J., Cai, F., 2019. Wealth, labor supply and life satisfaction: The case of urban housing demolition in China. Economics Letters, in press.

Li, H., Meng, L., Shi, X., Wu, B., 2012. Does attending elite colleges pay in China? Journal of Comparative Economics 40(1), 78-88.

Li, L., Wu, X., 2014. Housing price and entrepreneurship in China. Journal of Comparative Economics 42(2), 436-449.

Li, S. M., Song, Y. L., 2009. Redevelopment, displacement, housing conditions, and residential satisfaction: A study of Shanghai. Environment and Planning A 41(5), 1090-1108.

Lovenheim, M. F., 2011. The effect of liquid housing wealth on college enrollment. Journal of Labor Economics 29(4), 741-771.

Lu, Y., Shi, X., Zhong, S., 2018. Competitive experience and gender difference in risk preference, trust preference and academic performance: Evidence from Gaokao in China. Journal of Comparative Economics 46(4), 1388-1410.

Mao, G., Shen, Y., 2019. Bubbles or fundamentals? Modeling provincial house prices in China allowing for cross-sectional dependence. China Economic Review 53, 5364. 
Pan, J. N., Huang, J. T., Chiang, T. F., 2015. Empirical study of the local government deficit, land finance and real estate markets in China. China Economic Review 32, 57-67.

Picchio, M., Suetens, S., van Ours, J. C., 2017. Labour supply effects of winning a lottery. Economic Journal 128(611), 1700-1729.

Romano, J. P., Wolf, M., 2005a. Exact and approximate stepdown methods for multiple hypothesis testing. Journal of the American Statistical Association 100, 94-108.

Romano, J. P., Wolf, M., 2005b. Stepwise multiple testing as formalized data snooping. Econometrica 73(4), 1237-1282.

Romano, J. P., Wolf, M., 2016. Efficient computation of adjusted p-values for resampling-based stepdown multiple testing. Statistics \& Probability Letters 113, $38-40$.

Schultz, T. P., 2004. School subsidies for the poor: Evaluating the Mexican Progresa poverty program. Journal of Development Economics 74(1), 199-250.

van Huizen, T., 2014. More wealth, shorter hours? Evidence from the Netherlands. Economics Letters 125(2), 323-326.

Wong, S. W., 2015. Land requisitions and state-village power restructuring in southern China. The China Quarterly 224, 888-908.

Wrenn, D., Yi, J., Zhang, B., 2019. House prices and marriage entry in China. Regional Science and Urban Economics 74, 118-130.

Xiao, Y., Li, L., Zhao, L., 2017. Education on the cheap: The long-run effects of a free compulsory education reform in rural china. Journal of Comparative Economics 45(3), 544-562.

Xie, Y., Jin, Y., 2015. Household wealth in China. Chinese Sociological Review 47(3), 203-229.

Yao, S., Luo, D., Wang, J., 2014. Housing development and urbanisation in China. The World Economy 37(3), 481-500.

Zhang, Y., 2018. Domicide, social suffering and symbolic violence in contemporary Shanghai, China. Urban Geography 39(2), 190-213.

Zhang, Y., Fang, K., 2004. Is history repeating itself? From urban renewal in the United States to inner-city redevelopment in China. Journal of Planning Education and Research 23(3), 286-298.

Zou, J., Deng, X., 2019. Financial literacy, housing value and household financial market participation: Evidence from urban China. China Economic Review 55, 52-66. 